\title{
Future Hydrological Regimes in the Upper Indus Basin: A Case Study from a High-Altitude Glacierized Catchment
}

\author{
Andrea Soncini,* Daniele Bocchiola, ${ }^{+}$Gabriele Confortola, ${ }^{*}$ Alberto Bianchi,* \\ Renzo Rosso, ${ }^{*}$ CHRISTOPH MAYER, ${ }^{\#}$ ASTRID LAMBreCHT, ${ }^{\#}$ ElisA PALAZZI, ${ }^{@}$ \\ Claudio Smiraglia, \& AND GUGlielmina DiOlaiuti ${ }^{\&}$ \\ * Department of Civil and Environmental Engineering, Politecnico di Milano, Milan, Italy \\ ${ }^{+}$Department of Civil and Environmental Engineering, Politecnico di Milano, Milan, and Ev-K2-CNR Association, Bergamo, Italy \\ \# Bavarian Academy of Sciences, Munich, Germany \\ ${ }^{\circledR}$ Institute of Atmospheric Sciences and Climate, National Research Council, Turin, Italy \\ ${ }^{\&}$ Department of Earth and Environmental Sciences, University of Milan, Milan, Italy
}

(Manuscript received 28 February 2014, in final form 15 October 2014)

\begin{abstract}
The mountain regions of the Hindu Kush, Karakoram, and Himalayas (HKH) are considered Earth's "third pole," and water from there plays an essential role for downstream populations. The dynamics of glaciers in Karakoram are complex, and in recent decades the area has experienced unchanged ice cover, despite rapid decline elsewhere in the world (the Karakoram anomaly). Assessment of future water resources and hydrological variability under climate change in this area is greatly needed, but the hydrology of these high-altitude catchments is still poorly studied and little understood. This study focuses on a particular watershed, the Shigar River with the control section at Shigar (about $7000 \mathrm{~km}^{2}$ ), nested within the upper Indus basin and fed by seasonal melt from two major glaciers (Baltoro and Biafo). Hydrological, meteorological, and glaciological data gathered during 3 years of field campaigns (2011-13) are used to set up a hydrological model, providing a depiction of instream flows, snowmelt, and ice cover thickness. The model is used to assess changes of the hydrological cycle until 2100 , via climate projections provided by three state-of-the-art global climate models used in the recent IPCC Fifth Assessment Report under the representative concentration pathway (RCP) emission scenarios RCP2.6, RCP4.5, and RCP8.5. Under all RCPs, future flows are predicted to increase until midcentury and then to decrease, but remaining mostly higher than control run values. Snowmelt is projected to occur earlier, while the ice melt component is expected to increase, with ice thinning considerably and even disappearing below $4000 \mathrm{~m}$ MSL until 2100.
\end{abstract}

\section{Introduction}

The mountain range of the Hindu Kush, Karakoram, and Himalayas (HKH), known as the "third pole" of our planet (e.g., Smiraglia et al. 2007; Kehrwald et al. 2008; Minora et al. 2013), contains a large amount of glacier ice, delivering water for agriculture, drinking, and power production. According to recent estimates, more than $50 \%$ of the water flowing in the upper Indus basin, in northern Pakistan, is due to snow and ice melt (Immerzeel et al. 2010). Relying on agriculture, the economy of the Himalayan regions is highly dependent

Corresponding author address: Daniele Bocchiola, Department of Civil and Environmental Engineering, Politecnico di Milano, L. da Vinci 32, 20133 Milan, Italy.

E-mail: daniele.bocchiola@polimi.it on water availability and irrigation systems (e.g., Akhtar et al. 2008). The Indo-Gangetic Plain (IGP; including regions of Pakistan, India, Nepal, and Bangladesh) is challenged by increasing food production. Any perturbation in agriculture will considerably affect the food systems of the region and increase the vulnerability of the resource-poor population (e.g., Aggarwal et al. 2004; Kahlown et al. 2007). The HKH stores a considerable amount of water within its extensive glacier cover (about $16300 \mathrm{~km}^{2}$ ), while lower-altitude areas are very dry. Along the HKH range, there is considerable variability in climate conditions, including varying precipitation sources and types (e.g., Bocchiola and Diolaiuti 2013), influencing the behavior and evolution of the cryosphere. Eastern and central HKH glaciers are subject to general retreat and have lost a significant amount of mass and area in the last few decades (Bolch et al. 2011). 
Rapid decline in glacier area is reported throughout the greater Himalayas and most of mainland Asia (Ageta and Kadota 1992), widely attributed to global warming (Solomon et al. 2007; Alexander et al. 2013). On the other hand, positive ice mass balances and advancing glaciers have been reported in the Karakoram in the last decade (Hewitt 2005). While the southeastern Himalayas are strongly influenced by the monsoon, meteoclimatic conditions of the Karakoram indicate a stricter dependence of water resources on snow and ice ablation. Glaciers in the eastern part of the $\mathrm{HKH}$ receive their water input in summer owing to the monsoon, while in the west, precipitation occurs mainly in winter, carried by western weather patterns (Fowler and Archer 2005; Winiger et al. 2005; Bookhagen and Burbank 2010; Kääb et al. 2012). This variability in accumulation conditions may be one reason for the large spread in glacier changes within the whole region (Bolch et al. 2011; Kääb et al. 2012). Kääb et al. (2012) used satellite laser altimetry to show widespread glacier wastage in the eastern, central, and southwestern parts of the HKH, while in the Karakoram, glaciers seem to have thinned by a few centimeters per year. The glacier mass balance budget in the Karakoram positively affected the 2003-08 specific mass balance for the entire $\mathrm{HKH}$ region, which was estimated by Kääb et al. (2012) into $-0.21 \pm$ $0.05 \mathrm{~m} \mathrm{yr}^{-1}$ of water equivalent. In particular, some studies discuss the expansion and thickening of the largest glaciers, mainly in the central Karakoram, since the 1990s, accompanied by a nonnegligible number of rapid glacier advances (i.e., surge-type phenomena; see, e.g., Diolaiuti et al. 2003; Hewitt 2005; Barrand and Murray 2006; Mayer et al. 2011; Copland et al. 2011; Minora et al. 2013).

This situation of stagnant and advancing glaciers in the highest parts of central Karakoram was denoted the "Karakoram anomaly" (Hewitt 2005). The "PamirKarakoram anomaly" name was recently proposed by Gardelle et al. (2012), in view of the recent slight mass gain observed for glaciers in western Pamir. An overall decreasing trend in summer mean and minimum temperatures and an increasing trend in winter precipitation in recent decades have been derived from stations in the upper Indus basin (Archer and Fowler 2004; Bocchiola and Diolaiuti 2013), partly explaining the observed stability or thickening of some Karakoram glaciers, as well as the reduced runoff measured by gauging stations in heavily glacierized catchments of the area (e.g., in the Hunza basin; Hewitt 2005; Archer 2003; Sharif et al. 2013). Furthermore, this behavior might be a consequence of the generally high elevation of glaciers' bodies in this area and of the shielding effect of debris coverage and snow layer (also from avalanches) above the glaciers, combined with a possible increase in orographic precipitation leading to the largest accumulation (Scherler et al. 2011a; Minora et al. 2013).

The glaciological and hydrological regimes of the HKH and the potential impacts of climate change therein have been recently assessed in the literature (e.g., Aizen et al. 2002; Hannah et al. 2005; Kaser et al. 2010). Among others, Bocchiola et al. (2011) modeled future hydrological flows in the poorly gauged Shigar River, flowing at the toe of the K2 peak. They used a minimal hydrological model, including the representation of snow and ice ablation processes and driven by downscaled precipitation and temperature data from one global climate model (GCM), to describe the future (2050-59) hydrological behavior under four different glacier cover scenarios.

With respect to Bocchiola et al. (2011), the study presented here relies on data from new field campaigns and presents projections under the newest IPCC scenarios performed with the most recent state-of-the-art GCMs. The new database consists of 1) hydrological fluxes gathered at two stations operating during 2011-13, 2) ice melting factors evaluated through field campaigns during 2011-13, 3) supraglacial debris cover thickness from remote sensing measurements (Mihalcea et al. 2008) and from in situ field data collected during 2011-13, and 4) glacier surface velocity data gathered during some field campaigns (the most recent one during 2011-13). The modeling activity includes the 1) setup of a simple model of ice flow to avoid inconsistent "static" glacier cover, 2) validation of the snow cover module by using summer 2011 snow accumulation data, and 3) provision of hydrological projections until 2100 based on the output of three GCMs running under the most recent representative concentration pathway (RCP) scenarios. This study builds upon the activities carried out within the Stations at High Altitude for Research on the Environment-Cryospheric Responses to Anthropogenic Pressures in the Hindu Kush-Himalaya regions (SHARE-PAPRIKA) project, funded by the Everest-K2-National Research Council (Ev-K2-CNR) committee of Italy, aimed at evaluating the impact of climate change on hydrology of the upper Indus River, and in particular focusing on the Shigar River.

\section{Case study area}

The Shigar River flows within the HKH region in northern Pakistan, ranging from $35.2^{\circ}$ to $37^{\circ} \mathrm{N}$ in latitude and from approximately $74.5^{\circ}$ to $76.5^{\circ} \mathrm{E}$ in longitude. Our study focuses on the Shigar watershed with the control section at Shigar $\left(\sim 7000 \mathrm{~km}^{2}\right)$, nested within the 


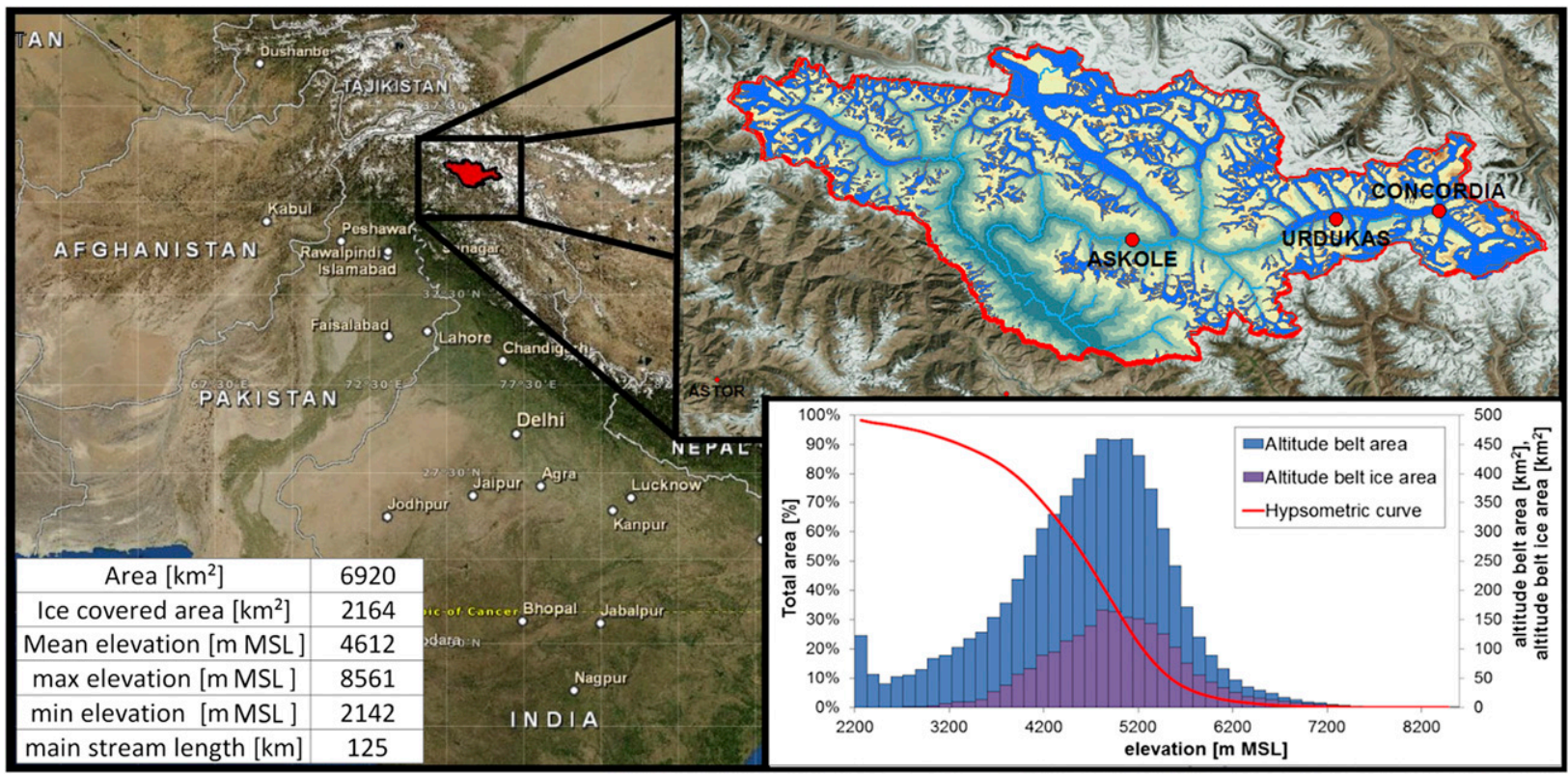

FIG. 1. Position and main features of the study area. In the lower-right subplot the hypsometric curve, the belts area, and ice area are reported.

upper Indus basin and fed mainly by seasonal melt from major glaciers of the area (Fig. 1).

The whole catchment is located in the Gilgit-Baltistan region, the highest altitude is the $\mathrm{K} 2$ peak $(8611 \mathrm{~m}$ MSL), and the outlet is at the Shigar bridge $(2204 \mathrm{~m}$ MSL). The average altitude of the catchment is $4613 \mathrm{~m}$ MSL, and more than $40 \%$ of the area lies between 4000 and $5000 \mathrm{~m}$ MSL. The catchment includes several glaciers, covering an area of $2164 \mathrm{~km}^{2}(28 \%$ of the basin area), the most important being the Biafo glacier $\left(438 \mathrm{~km}^{2}\right)$ and the Baltoro glacier $\left(604 \mathrm{~km}^{2}\right)$. According to the Köppen-Geiger climate classification (Peel et al. 2007), the region has a typical "cold desert" climate (BWk), that is, a dry climate with little precipitation and large daily temperature range. The main contribution to the hydrological regime of the area comes from snow and ice melt, while the contribution from summer (monsoon) rainfall is small. In particular, looking at Askole climate data, precipitation has a maximum in April, and $44 \%$ of the total annual rainfall is concentrated in March-May, the rest being equally distributed.

Studies on precipitation gradients in the mountain regions of northern Pakistan are scarce because of the limited availability and accuracy of high-elevation data. Some studies indicate a total annual rainfall between 200 and $500 \mathrm{~mm}$, but these amounts are generally derived from valley-based stations and are not representative of the situation encountered in the highest accumulation zones (e.g., Archer 2003). Recent estimates (C. Mayer et al. 2012, unpublished data) from high-altitude accumulation pits (above $5500 \mathrm{~m}$ MSL) indicate from 6 to $8 \mathrm{~m}$ of snow depth [ $\sim 3 \mathrm{~m}$ snow water equivalent (SWE)] during 2009-11 in the study area. Recent studies show that precipitation is at maximum around $5000 \mathrm{~m}$ MSL and decreases rapidly there above (Immerzeel et al. 2012a).

\section{Database}

\section{a. Observed data}

Our study is based on the analysis of meteorological, hydrological, and glaciological data from various in situ stations in the Shigar River catchment, as summarized in Table 1. Three stations, managed by the Ev-K2-CNR committee, are located at Askole (3015 m MSL) and Urdukas (3926 m MSL), providing data since 2005, and at Concordia (4690 m MSL), operating since 2011. Daily data of rainfall, air temperature, and other standard meteorological parameters are available at the three stations. The datasets show some gaps, especially during winter, because of sensor malfunctioning in extreme weather conditions. Monthly meteorological data for the period 1980-2009 from other stations managed by the Pakistan Meteorological Department (PMD), located outside the catchment below $2500 \mathrm{~m}$ MSL (Bocchiola and Diolaiuti 2013) have also been used, most notably to assess lapse rates of temperature and precipitation.

We used mean monthly discharge estimates at Shigar during 1985-97 (Archer 2003, his Table 3). These data come from a station managed by the Water and Power 
TABLE 1. Data coverage.

\begin{tabular}{lcccllc}
\hline \hline Station & Alt $(\mathrm{m} \mathrm{MSL})$ & Lat $\left({ }^{\circ} \mathrm{N}\right)$ & Lon $\left({ }^{\circ} \mathrm{E}\right)$ & & Resolution & Period \\
\hline Askole & 3015 & 35.68 & 75.82 & Temp, precipitation & Daily & $2005-12$ \\
Astore & 2168 & 35.36 & 74.87 & Temp, precipitation & Monthly & $2005-12$ \\
Concordia & 4690 & 35.44 & 76.31 & Temp, precipitation, snow depth & Daily & $2011-12$ \\
Shigar & 2221 & 35.42 & 75.73 & Discharge & Daily & 23 May-25 Jun 2012 \\
Paiju & 3356 & 35.40 & 76.06 & Discharge & Daily & 23 May-25 Jun 2012 \\
17 & $3693-4580$ & - & - & Ice ablation & Various & Jul 2011-Jun 2012 \\
Three & $5600-5900$ & - & - & SWE, snow depth & Three samples & Aug 2011 \\
Concordia & 4960 & 35.44 & 76.31 & Ice thickness & One measure & Jun 2013 \\
Urdukas & 3926 & 35.73 & 76.29 & Temp, precipitation & Daily & $2005-11$ \\
\hline
\end{tabular}

Development Authority (WAPDA) of Pakistan. We further used daily discharge data available since April 2011 from a new hydrometric station (sonic ranger for water level, plus stage-discharge curve) that we installed in Shigar. A second hydrometric station (pressure transducer for water level, plus stage-discharge curve) was installed in Paiju (3356 m MSL), near the Baltoro glacier's snout in May 2012. Spring 2012 data from the Paiju station have been used to validate the hydrological model at this section.

Along the main flow line of the Baltoro glacier, from 3700 to $4600 \mathrm{~m}$ MSL, 17 ablation stakes were deployed (Fig. 3, described in greater detail below) in summer 2011 , by coring ice with a steam drill down to $8-12 \mathrm{~m}$. The stakes were also used to evaluate surface ice flow velocity by performing differential GPS (DGPS) surveys during two summer seasons (2011 and 2012). For this purpose, we used three Trimble GPS receivers, one master at a fixed reference point and two slaves used on the glacier surface. During summer 2011, three snow pits were dug in the accumulation area of Baltoro glacier (Table 1) and the data were used to validate snow accumulation by the model. Ice thickness on the Baltoro glacier was also tentatively estimated in summer 2013 (C. Mayer 2012, unpublished data), using a lowfrequency radar antenna $(50 \mathrm{MHz})$ installed on a portable instrument [subsurface interface radar (SIR 3000)] to be used in our simple ice flow model.

\section{b. GCM data}

In this study, we used the outputs of historical and scenario (up to 2100) simulations of three GCMs participating in phase 5 of the Coupled Model Intercomparison Project (CMIP5) and contributing to the Fifth Assessment Report (AR5) of the IPCC, namely, EC-EARTH, ECHAM6, and CCSM4 (Table 2). Climate projections are evaluated under RCP scenarios (Moss et al. 2010; Alexander et al. 2013), all including progressive decreases in aerosol (and aerosol precursors) emissions through the twenty-first century. Here, we used results from RCP2.6, RCP4.5, and RCP8.5, where the number indicates the radiative forcing $\left(\mathrm{W} \mathrm{m}^{-2}\right)$ in 2100 , relative to 1850 . In the framework of the SHARE-PAPRIKA project, the ECEARTH precipitation data for the historical period and two future scenarios were specifically analyzed for the HKH area (Palazzi et al. 2013). Precipitation in the HKH region simulated by EC-EARTH was found to represent the climatology of different observational and reanalysis datasets well, that is, reflecting the main seasonal precipitation patterns in the area, the wintertime western weather patterns, and the summer monsoon. ECEARTH slightly overestimated precipitation, particularly in winter, consistent with the "wet bias" commonly seen in precipitation simulated by GCMs over highelevation terrains. Also, this bias may be related to an underestimation of total precipitation in snow-rich areas like HKH. Typically, the coarse spatial resolution of GCMs leads to poor simulation of the effects of rapidly changing topography, for example, precipitation changes over short distances, and their spatial variability in general. A spatial downscaling of the outputs of climate models is required to extract local information from coarse-scale simulations and to perform hydrological/ impact studies at a basin scale (e.g., Groppelli et al. 2011a).

\section{Methods}

\section{a. Weather data}

We explored the vertical variability of temperature and precipitation using monthly meteorological data

TABLE 2. Features of the three adopted GCMs.

\begin{tabular}{|c|c|c|c|c|c|}
\hline Model & Research Center & Location & Grid size & No. layers & No. cells \\
\hline EC-EARTH & EC-Earth Consortium & European Union & $1.125^{\circ} \times 1.125^{\circ}$ & 62 & $320 \times 160$ \\
\hline ECHAM6 & Max Planck Institute for Meteorology & Germany & $1.875^{\circ} \times 1.875^{\circ}$ & 47 & $192 \times 96$ \\
\hline CCSM4 & National Center for Atmospheric Research & United States & $1.25^{\circ} \times 1.25^{\circ}$ & 26 & $288 \times 144$ \\
\hline
\end{tabular}


from PMD stations at different elevations and available during 1980-2009, and daily data collected at the Ev-K2CNR stations and available since 2005. The monthly temperature lapse rates were evaluated by exploiting all station data, and the linear regression parameters were calculated for each month. Assessing the vertical gradient of precipitation was more difficult, because few dependable data are available at the highest altitudes, either from in situ stations or from satellite devices (e.g., Bocchiola et al. 2011).

In the present literature there is little knowledge of precipitation above $5000 \mathrm{~m} \mathrm{MSL}$, and above that altitude large uncertainties are entailed in hydrological modeling. Among others, Young and Hewitt (1990) stated that maximum precipitation in the Himalayas is likely near $5000 \mathrm{~m}$ MSL. More recently, Bookhagen and Burbank (2006) used Tropical Rainfall Measuring Mission (TRMM) data to investigate precipitation against topography. For western Karakoram they found maximum precipitation near $5000 \mathrm{~m}$ MSL, and then it decreased to very low values near $7000 \mathrm{~m}$ MSL. Recently, Immerzeel et al. (2012a) applied an inverse approach to estimate the spatial distribution of precipitation within the Hunza catchment, north of the Shigar River, starting with the glaciers' mass balance and applying a simplified hydrological model. They used a linearly increasing vertical lapse rate until $5500 \mathrm{~m}$ MSL and then used a decreasing precipitation gradient, with acceptable results.

Upon verification against the available precipitation data (though located at low altitudes), we used a power law (Winiger et al.2005) to estimate the precipitation dependence on the altitude $z$, up to peak value $z_{p}=5000 \mathrm{~m}$ MSL. Above that altitude, we hypothesized a linear precipitation decrease toward zero at the low limit value $z_{l}=7000 \mathrm{~m}$ MSL, according to the results reported above, displaying sensible decrease of precipitation at the highest altitudes (Anders et al. 2006; Bookhagen and Burbank 2006). Notice that the area located above $7000 \mathrm{~m}$ MSL covers $0.34 \%$ of the entire basin area, meaning that although the hypothesis of no precipitation at this elevation may be extreme, it carries little bearing on the global budget of the basin. Eventually, we assumed a vertical dependence of precipitation against elevation as

$$
\begin{aligned}
& P_{y}=9 \times 10^{-6}\left(z^{2.22}\right) \quad z \leq z_{p}=5000 \mathrm{~m} \mathrm{MSL} \\
& P_{y}=9 \times 10^{-6}\left(z_{p}^{2.22}\right)-\left(z-z_{p}\right) \frac{9 \times 10^{-6}\left(z_{p}^{2.22}\right)}{\left(z_{l}-z_{p}\right)} \quad z>z_{p}=5000 \mathrm{~m} \mathrm{MSL},
\end{aligned}
$$

where $P_{y}$ is the yearly amount of precipitation $(\mathrm{mm})$. Bocchiola et al. (2011), investigating snow accumulation at high altitudes in the Baltoro glacier area, found a likely overestimation of snow accumulation when taking precipitation as monotonically increasing. Here, we carried out a comparison against accumulation data from high-altitude snow pits dug in 2011, to test the performance of the model.

Following the methodology described in Bocchiola et al. (2011), we performed a daily disaggregation of monthly precipitation at the Astore station. Daily precipitation from the Askole station available since 2005 were used to calibrate the disaggregation model, and two 1980-2013 precipitation and temperature daily series were built for the Astore station were used to feed the hydrological model.

\section{b. Ice and snow ablation}

The Shigar watershed includes several glaciers, displaying a large debris cover that affects the melting dynamic (Scherler et al. 2011b). Mihalcea et al. (2006) and Mayer et al. (2006) evaluated melt factors for both debris-covered and debris-free ice, based on field ablation data from the Baltoro glacier. Mihalcea et al. (2008) used remote sensing and field data to develop a debris thickness map of the Baltoro. Based on data from our 17 ice ablation stakes deployed in 2011 between 3700 and $4600 \mathrm{~m}$ MSL, we built a degree-day factor approach for computing ice melt, both for buried and bare ice. A positive degree-day factor (PDDF) was estimated (melting threshold $0^{\circ} \mathrm{C}$ ) using our ice ablation data. Also, using data from ablation stakes and from sparse surveys of debris cover at randomly selected sites during summer 2011, we found a relationship of debris thickness against altitude, which we used to estimate (average) debris cover thickness within our elevation belts. Snowmelt was also tackled using a degree-day model. For this study, we used a seasonally variable degree-day factor for snowmelt $D_{\mathrm{Ds}}$ estimated from Moderate Resolution Imaging Spectroradiometer (MODIS) snow cover images (Bocchiola et al. 2011). This starts from $D_{\mathrm{Ds}}=1.5 \mathrm{~mm}^{\circ} \mathrm{C}^{-1} \mathrm{day}^{-1}$ in April (onset of snowmelt season at the lowest altitudes), increases monthly until $D_{\mathrm{Ds}}=5 \mathrm{~mm}^{\circ} \mathrm{C}^{-1}$ day $^{-1}$ in August, and then decreases again until $D_{\mathrm{Ds}}=1.5 \mathrm{~mm}^{\circ} \mathrm{C}^{-1}$ day $^{-1}$ 
in October. Overall, an average value was obtained of $D_{\text {Ds }}=2.5 \mathrm{~mm}^{\circ} \mathrm{C}^{-1}$ day $^{-1}$. We used snow depth data collected at Concordia station (4690 m MSL) from winter 2011 to summer 2012 to further validate the snow ablation model performance.

\section{c. The glaciohydrological model}

In this study, we used a semidistributed altitude beltsbased model (Groppelli et al. 2011b; Bocchiola et al. 2011), able to reproduce ice and snow dynamics, evapotranspiration, recharge of groundwater reservoir, discharge formation, and routing to the control section. This model needs some input data, including a DEM, daily values of precipitation and temperature, information about soil use, vertical gradient of temperature, and precipitation. The model may be viewed as a simplified version of a distributed hydrological model (Wigmosta et al. 1994; Chen et al. 2005), and it considers superficial and groundwater flow formation. Full model equations are reported, for example, in Groppelli et al. (2011b) and Bocchiola et al. (2011), and the reader is referred there for details. Here, we introduced a module designed to take into account glacier flow as driven by gravity. Specifically, the model uses a simplified ice flow approach, by shifting a proper quantity of ice from an altitude belt to the lower one. The large valley glaciers in the Karakoram flow with maximum speeds of about $100-150 \mathrm{~m} \mathrm{yr}^{-1}$, while the glacier tongues are on the order of $20-40 \mathrm{~km}$ long (e.g., Mayer et al. 2006; Quincey et al. 2011). Simulations of glacier runoff with periods of 50-100 years lead to an ice movement of $5-15 \mathrm{~km}$, that is, less than half of the glacier tongue length. Therefore, we decided to use only a crude implementation of ice flow in the hydrological model, which represents a simple but efficient way of adapting the glaciers' geometry to the mass balance conditions. In this case, the velocity can be approximated by a simplified force balance, and it is proportional to ice thickness raised to $(n+1)$, where $n$ is the exponent of Glen's flow law $(n=3$; e.g., Wallinga and van de Wal 1998; Cuffey and Paterson 2010). In the simplifying hypothesis that basal shear stress $\tau_{b}$ is constant along the glacier, and accounting for both deformation and basal sliding velocity as governed by $\tau_{b}$, it is possible to model depth-averaged ice velocity as (Oerlemans 2001)

$$
\begin{aligned}
V_{\mathrm{ice}, i} & =f_{d} \tau_{b}^{n} h_{\mathrm{ice}, i}+f_{b} \frac{\tau_{b}^{n}}{h_{\mathrm{ice}, i}}=K_{d} h_{\mathrm{ice}, i}^{n+1}+K_{b} h_{\mathrm{ice}, i}^{n-1} \\
& =K_{d} h_{\mathrm{ice}, i}^{4}+K_{b} h_{\mathrm{ice}, i}^{2},
\end{aligned}
$$

with $h_{\text {ice, } i}(\mathrm{~m})$ representing the ice water equivalent in the belt $i, f_{b}\left(\mathrm{~m}^{6} \mathrm{~s}^{-1} \mathrm{~N}^{-3}\right)$ and $f_{d}\left(\mathrm{~m}^{6} \mathrm{~s}^{-1} \mathrm{~N}^{-3}\right)$ representing the Oerlemans basal sliding and internal deformation coefficient, and $K_{b}\left(\mathrm{~m}^{-3} \mathrm{yr}^{-1}\right)$ and $K_{d}\left(\mathrm{~m}^{-1} \mathrm{yr}^{-1}\right)$ representing parameters of basal sliding and internal deformation, which we calibrated against the observed velocity values at the stakes. Ice flow occurs then by

$$
\begin{aligned}
h_{\text {ice }, i}(t+\Delta t)= & h_{\text {ice }, i}(t)-F_{i \rightarrow i-1}(t) \\
& +F_{i+1 \rightarrow i}(t) F_{i \rightarrow i-1} \propto V_{\text {ice }, i},
\end{aligned}
$$

where the amount of $h_{\text {ice, } i}$ in the belt $i$ at time $t$ results from the balance of the ice passing from belt $i$ to the lower belt $i-1\left(F_{i \rightarrow i-1}\right)$ and from belt $i+1$ to the lower belt $i\left(F_{i+1 \rightarrow i}\right)$, with ice mass passing proportional to velocity in the upper belt (and scaled by the ratio of the ice-covered area in belt $i$ and the one in the belt $i-1$ or $i+1)$. To initialize the ice flow model, we estimated the ice thickness value for each belt. We started from calculation of $\tau_{b}$ from altitude range $\Delta H$ (difference between maximum and minimum glacier elevation), according to Baumann and Winkler (2010). Here $\tau_{b}$ is set to 1.5 bar, because $\Delta H>1.6 \mathrm{~km}$. From ASTER Global Digital Elevation Map (GDEM), we calculated the slope in each belt $\alpha_{i}$ and then $h_{\text {ice, } i}$ by

$$
\tau_{i}=\rho g h_{\text {ice }, i} \sin \alpha_{i}=\tau_{b} .
$$

Therein, $\tau_{i}$ (bar) is the basal shear stress in the belt $i$ (equal to $\tau_{b}$ ), $\rho$ is ice density $\left(\mathrm{kg} \mathrm{m}^{-3}\right)$, and $g$ is gravity $\left(\mathrm{m} \mathrm{s}^{-2}\right)$. The calculated ice thickness ranged between $50 \mathrm{~m}$ in the high-altitude belts and $800 \mathrm{~m}$ in Concordia. Processing the low-frequency radar data gathered in Concordia in summer 2013, we estimated approximately 850-m ice thickness (Table 1), rather similar to the estimate above. From the DGPS surveys of the ablation stakes position as reported above, we estimated the surface velocity of the glacier, which could be used to calibrate our model depicting ice flow (see section $4 \mathrm{~d}$ ), by approximating depth-averaged ice velocity as $80 \%$ of surface velocity (Cuffey and Paterson 2010). The ice flow module is routed once a year (on 1 November), by using ice depth as resulting from seasonal mass budget (i.e., between ice ablation and accumulation under snow form; millimeters of water equivalent). Avalanche nourishment on the glaciers is accounted for within the model by considering the terrain slope. When ground slope is larger than a given threshold, progressively more snow detaches (linearly increasing within $30^{\circ}-60^{\circ}$ ) and falls in the flattest altitude belt downstream, where it could melt or transform into ice. Once a year, $10 \%$ of snow surviving at the end of the ablation season is shifted into new ice (i.e., full ice formation requires 10 years).

The equations of our model are solved using here 50 equally spaced elevation belts inside the basin. The 
TABLE 3. Hydrological model parameters. Boldface values are calibrated against observed discharges.

\begin{tabular}{|c|c|c|c|c|}
\hline Parameter & Unit & Description & Value & Method \\
\hline$k_{g}, k_{s}$ & days & Reservoir time constant, ground or overland & 30, 3 & Basin morphology \\
\hline$n_{g}, n_{s}$ & - & Reservoirs, ground or overland & $3 / 3$ & Literature \\
\hline$K$ & $\mathrm{~mm}_{\text {day }}{ }^{-1}$ & Saturated conductivity & 2 & Calibration \\
\hline$K$ & - & Groundwater flow exponent & $\mathbf{1}$ & Calibration \\
\hline$F_{v}$ & $\%$ & Vegetation cover, average & 30.9 & Soil cover \\
\hline$\theta_{w}, \theta_{l}$ & - & Water content, wilting or field capacity & $0.15,0.35$ & Literature \\
\hline$S_{\text {Max }}$ & $\mathrm{mm}$ & Max soil storage, average & 86.2 & Soil cover \\
\hline$D_{\text {DS }}$ & $\mathrm{mm}{ }^{\circ} \mathrm{C}^{-1} \mathrm{day}^{-1}$ & Degree-day factor for snow, average & 2.33 & Remote sensing \\
\hline$D_{\text {DI }}$ & $\mathrm{mm}{ }^{\circ} \mathrm{C}^{-1}$ day $^{-1}$ & Degree-day factor for ice, average & 5.65 & Ablation stakes \\
\hline$K_{d}$ & $\mathrm{~m}^{-1} \mathrm{yr}^{-1}$ & Ice flow internal deformation coefficient & $3.1 \times 10^{-10}$ & Ice stakes, literature \\
\hline$K_{b}$ & $\mathrm{~m}^{-3} \mathrm{yr}^{-1}$ & Ice flow basal sliding coefficient & $5.0 \times 10^{-6}$ & Ice stakes, literature \\
\hline
\end{tabular}

discharges from the belts are routed to the outlet section through a semidistributed flow-routing algorithm, based on the conceptual model of the instantaneous unit hydrograph (e.g., Rosso 1984). For calculation of the instream discharge, we hypothesized two (parallel) systems (groundwater $g$ and overland $s$ ) of linear reservoirs (in series), each one with a given number of reservoirs $\left(n_{g}\right.$ and $n_{s}$ ). Each of these reservoirs possesses a time constant $\left(k_{g}\right.$ or $\left.k_{s}\right)$. For every belt, the time lag is proportional to the altitude jump to the outlet section. The hydrological model uses a daily series of precipitation and temperature from one representative station, here Askole, and the adopted vertical gradients to project those variables at each altitude belt. Topography is represented here by a digital elevation model (DEM), with 30-m spatial resolution, derived from the ASTER mission (JPL 2014) and used to define altitude belts and local weather variables against altitude. Glaciers boundaries from Minora et al. (2013) were used.

\section{d. Hydrological model calibration}

We ran a 33-yr (1980-2012) simulation to obtain daily estimates of instream discharge at Shigar bridge. We then estimated the average values (1985-97) of the monthly mean discharges in the Shigar River (thus obtaining 12 average values, one for each month), and compared them against those estimated by Archer (2003, his Table 3) using WAPDA data during 1985-2007. During 2012, we compared the daily simulated discharges against the daily measured discharges from our station. Because of the lack of daily data for longer periods (only 2012 is available), it was not possible to pursue a calibration/validation strategy using data subsets. In Table 3 the parameters estimated via calibration are reported, together with those estimated a priori based on the available literature, for example, wilting point for vegetated areas $\theta_{w}=0.15$ (Chen et al. 2005; Wang et al. 2009) and field capacity $\theta_{l}=0.35$ (e.g., Ceres et al. 2009). Reservoir number for overland flow (e.g., Rosso 1984) are set to $n_{s}=3$ based on several studies. Similarly, the number of groundwater reservoirs was set $n_{g}=3$. Larger variability dwells in the appraisal of the time constants $k_{s}$ and $k_{g}$ that define the lag time of the catchment and are linked to its size and characteristic flow velocity (e.g., Bocchiola and Rosso 2009). We tuned the remaining parameters (see Table 3), maximizing the model fitting capability in reproducing the yearly average discharge, the observed monthly values from Archer (2003) and the daily values from our station. In particular, we considered as goodness indicators the NashSutcliffe efficiency coefficient (NSE) and root-meansquare error in percentage [RMSE (\%)] (see Table 4).

\section{e. GCM downscaling}

To evaluate future hydrological scenarios, we pursued downscaling of the three GCMs' precipitation and temperature data. A temporal disaggregation was carried out using the theory of stochastic space random cascade (SSRC; e.g., Groppelli et al. 2011a). The SSRC was tuned using the 1980-2013 daily series of

TABLE 4. Flow statistics and indicators for validation. Bias is percentage mean error.

\begin{tabular}{llccc}
\hline \hline Variable & \multicolumn{1}{c}{ Description } & Mean $\left(\mathrm{m}^{3} \mathrm{~s}^{-1}\right)$ & Bias (\%) & RMSE (\%) \\
\hline$Q_{\text {mean }, C}$ & Observed discharge, Shigar 1985-97 & 203 & - & - \\
$Q_{\text {mean }, M}$ & Model discharge, Shigar 1985-97 & 202 & -0.79 & 3.19 \\
$Q_{2012, C}$ & Observed discharge, Shigar, May-Nov 2012 & 295 & - \\
$Q_{2012, M}$ & Model discharge, Shigar, May-Nov 2012 & 305 & 3.42 & - \\
$Q_{2012, C, P}$ & Observed discharge, Paiju, May-Jun 2012 & 29 & - \\
$Q_{2012, M, P}$ & Model discharge, Paiju, May-Jun 2012 & 25 & -13.4 & 0.94 \\
\hline
\end{tabular}


precipitation and temperature at Askole, obtained as reported in section $4 \mathrm{a}$. The downscaling approach using SSRC corrects the daily precipitation bias. After the calculation of the area-averaged precipitation at the gauging station on the catchment $R_{\mathrm{GA}}$ (where GA indicates gauge averaging) for the control period, the area-averaged rainfall from the GCM $R_{\mathrm{GCM}}$ has been corrected by a random multiplicative process explicitly considering intermittence (i.e., occurrence of dry spells). In particular, a constant term is used to force the average daily value of precipitation from the GCM to equate its observed value, because of the GCM misestimation during wet spells. In addition, a $\beta$ model (with binomial distribution) generator is used to evaluate the probability that the rain rate for a given day is not zero, conditioned on GCM precipitation being positive. Finally, a "strictly positive" generator added a proper amount of variability to precipitation during spells labeled as wet.

Model estimation of SSRC is extensively explained elsewhere (Groppelli et al. 2011a). The estimated parameters were then used to disaggregate the future precipitation projected by each model under the three RCP scenarios, overall obtaining nine high-resolution time series until 2100. Temperature downscaling was also carried out by exploiting the Askole station series. A monthly averaged temperature additive shift $\Delta T$ approach and vertical lapse rate from the data were used to project the temperature value at each belt (Groppelli et al. 2011b).

\section{f. Hydrological projections}

Glaciohydrological projections were carried out by feeding the hydrological model with the precipitation and temperature scenarios obtained above. We carried out the simulations during 2012-2100, and then focused on two reference decades, 2045-54 and 2090-99. We calculated a number of flow descriptors, including monthly averaged flows, and some other indicators. First, we drew some flow descriptors taken by flow duration curves (FDCs; e.g., Smakhtin 2001), namely, the values of discharge equaled or exceeded for a given number of days $d$, that is, $Q_{d}$. We considered flow exceeded for $10 \%$ of the time $Q_{37}$, flow exceeded for $25 \%$ of the time (also known as ordinary flood) $Q_{91}$, median flow $Q_{182}$, and ordinary low flow $Q_{274}$. Also, we evaluated some flow frequency descriptors given by the yearly maxima and minima of average flows for a given duration $d$, that is, $Q_{M, d}$ and $Q_{m, d}$. Analysis of these variables is used to pursue statistical appraisal of low/high flows, for example, for hydrological drought/flood hazard analysis (e.g., Smakhtin 2001). We analyzed the projected amount of snow water volume per altitude belt averaged on the reference decades to highlight modified storage of water in snow and seasonal snow line. To

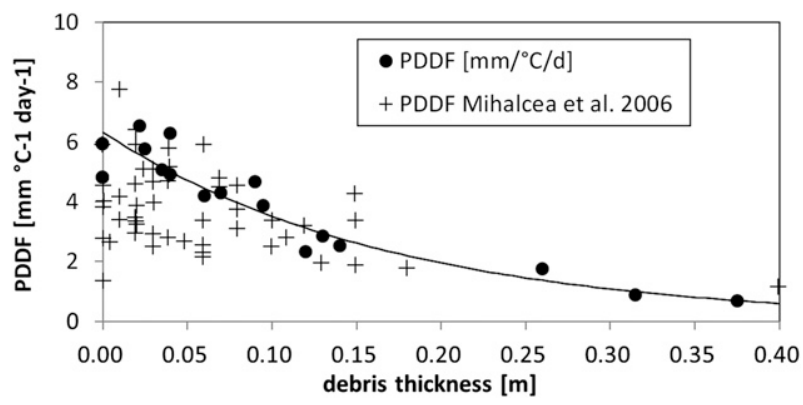

FIG. 2. Ice PDDF against supraglacial debris cover thickness on Baltoro glacier (ablation measured from summer 2011 to summer 2012) compared with the PDDF values by Mihalcea et al. (2006).

highlight the potential evolution of ice bodies until the end of the century, we analyzed the projected amount of ice per altitude bin, providing an indication of glacier downwasting and of remaining water resources stored into ice.

\section{Results}

\section{a. Ice ablation and flow}

In Fig. 2, we report 1) PDDFs against debris thickness at our stakes (and for bare ice) and 2) PDDFs observed by Mihalcea et al. (2006), which closely resemble each other. Also, our belt-averaged debris thickness closely matches that by Mihalcea et al. (2008, not shown). Using the debris cover map produced by Mihalcea et al. (2008), built upon a DEM from the Shuttle Radar Topography Mission (SRTM; 90-m resolution), we calculated ice ablation on a 90-m grid by assigning to debris thickness in each cell the PDDF from Fig. 2. Ablation on this grid was then averaged on each of our belts. Then, we calculated ablation in each belt using the PDDF corresponding to the average debris thickness within that belt, estimated from field data. The calculation period covered 1-15 July 2004, during which the data in Mihalcea et al. (2008) were acquired. We then compared the two values of ablation thus obtained in each belt [using average debris thickness from field data and using debris thickness from the $90-\mathrm{m}$ resolution map of Mihalcea et al. (2008)] and on the whole glacier, finding very good agreement [an increase of $3.9 \%$ on the whole glacier with respect to Mihalcea et al. (2008)]. The same comparison was made during July 2012, with similar results $(-0.45 \%$ on the whole glacier). Also, we compared the estimated ice ablation in our elevation belts (and with our PDDFs in Fig. 2) from 19 June to 1 August 2004 against that measured in the same period from three ablation stakes placed by personnel of the Università degli Studi di Milano [reported in Mihalcea et al. (2006)]. The results indicated that our model properly 


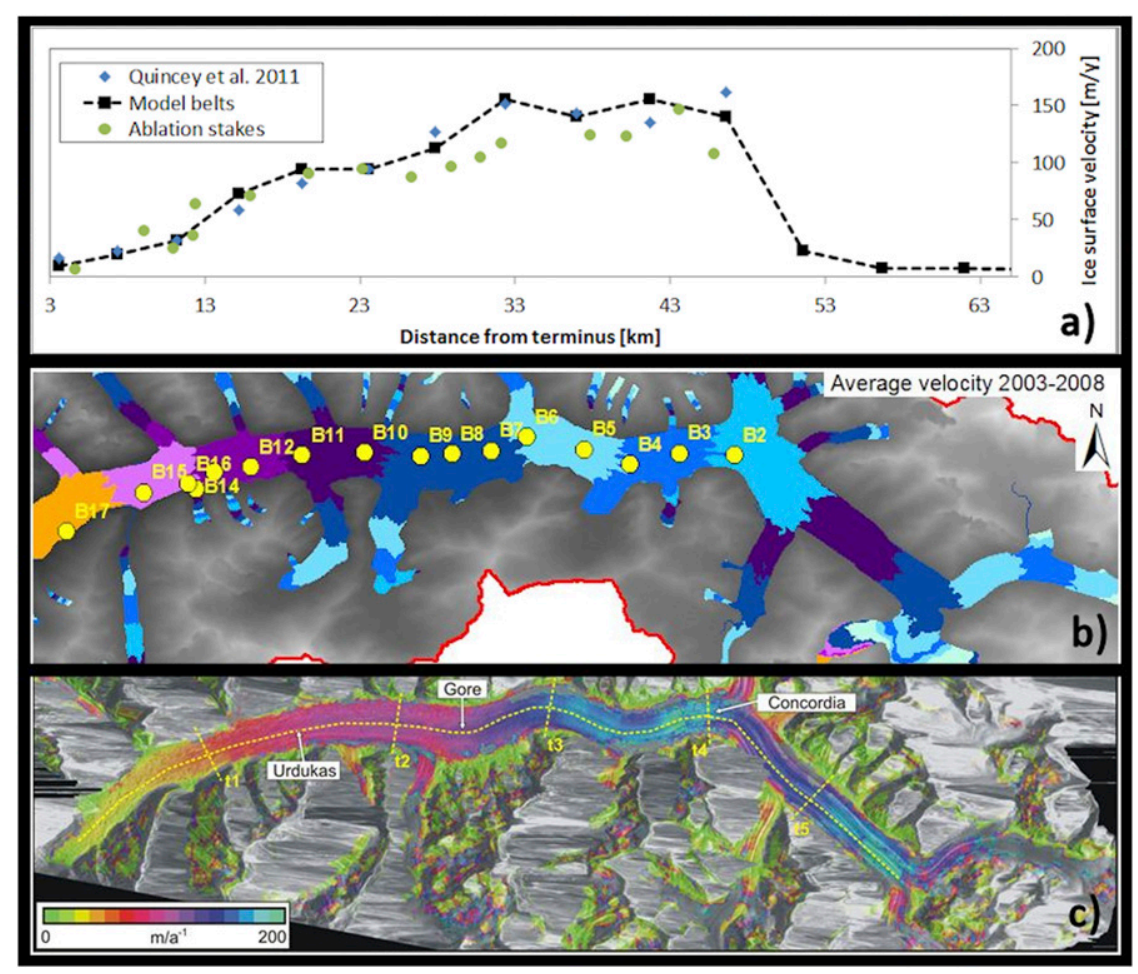

FIG. 3. (a) Comparison between ice flow velocity from model, ablation stakes, and remote sensing (Quincey et al. 2011). (b) Modeled and (c) estimated ice flow velocity using satellite images (Quincey et al. 2011). Same color scale is used in (b),(c). Ice stakes used for DGPS survey (B2-B17) reported.

matches (an increase of $6.8 \%$, with our model providing a slight overestimation) ablation measured in that independent field campaign. We therefore decided to use the average debris cover thickness in each belt and the corresponding PDDF for the purpose of estimating ice ablation. This allowed a faster computational approach (because ice ablation is calculated in each belt, rather than in each single 30-m cell of the ASTER GDEM, or in each 90-m cell of the SRTM DEM), while still providing an acceptable depiction of ice ablation.

Figure 3 displays the estimated stake velocity per elevation calibrated from the ablation stake position. Our measured surface velocity ranges from 10 to $120 \mathrm{~m} \mathrm{yr}^{-1}$ along the main flow line, which compares visually well against the velocities estimated by Quincey et al. (2011), using six Envisat Advanced Synthetic Aperture Radar images during 2003-08.

The modeled ice flow velocity resembles the velocity patterns estimated by Quincey et al. (2011) reasonably well with an RMSE of $20.6 \mathrm{~m} \mathrm{yr}^{-1}$, while slightly overestimating point velocity at stakes above $4000 \mathrm{~m}$ MSL $(23 \mathrm{~km})$. The mean velocity estimated by Quincey et al. (2011) is $107 \mathrm{~m} \mathrm{yr}^{-1}$, that from our model being $101 \mathrm{~m} \mathrm{yr}^{-1}$. The mean stakes velocity (used for calibration) is $83 \mathrm{~m} \mathrm{yr}^{-1}$, while velocity from Quincey et al. (2011) in the same altitude range (3700-4600) averages $90 \mathrm{~m} \mathrm{yr}^{-1}$, and the one from the model is $89 \mathrm{~m} \mathrm{yr}^{-1}$. Therefore, we assume that our model depicts ice flow reasonably well, for the sole purpose of carrying out a hydrological budget of the catchment.

\section{b. Hydrological model simulations results}

We evaluated the hydrological model capabilities in providing an acceptable depiction of 1) average monthly flows against those provided by the WAPDA hydrometric station in Shigar (1985-97) and 2) daily flows against those measured during 2012 from our hydrometric station in Shigar, which could be validated and used during May-November 2012 (technical problems and battery damage made it difficult to use data before and after; the station was fixed in June 2013 and is now operating normally), covering most of the ablation season that year. Concerning instream flows, calibration parameters and main validation statistics are reported in Table 4. The model estimates during 1985-97 a mean annual discharge value (expressed as per millimeter per year on the catchment area) of $925 \mathrm{~mm} \mathrm{yr}^{-1}$ against an observed value of $920 \mathrm{~mm} \mathrm{yr}^{-1}$ (bias $=-0.79 \%$ ). For 


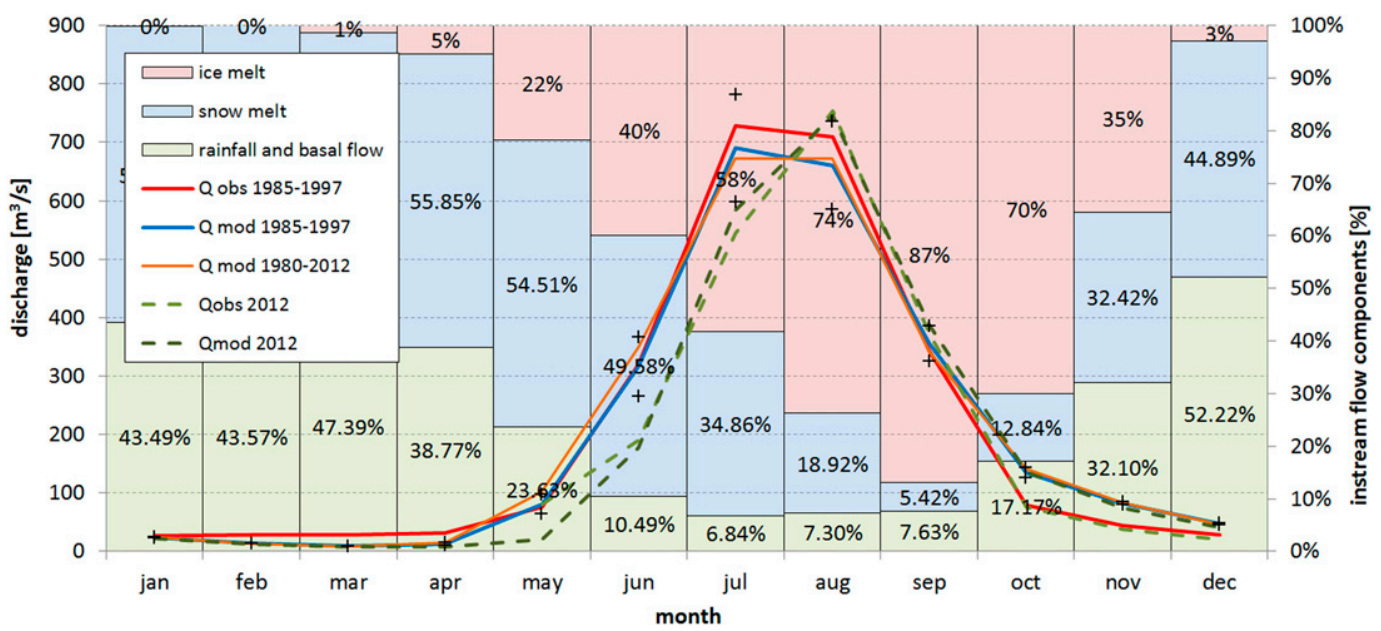

FIG. 4. Hydrological model calibration and flow components (rainfall, ice melt, and snowmelt) estimated by the model.

the year 2012, the values during May-November are $1389 \mathrm{~mm} \mathrm{yr}^{-1}$ from the model and $1344 \mathrm{~mm} \mathrm{yr}^{-1}$ from observations. As a comparison, the average value for May-November during 1985-97 was $1499 \mathrm{~mm} \mathrm{yr}^{-1}$, thus indicating that 2012 was a slightly drier year than usual. Modeled values during 2012 (yearly) yielded $847 \mathrm{~mm} \mathrm{yr}^{-1}$, also lower than the average of 1985-97, which was $920 \mathrm{~mm} \mathrm{yr}^{-1}$. In Fig. 4 we report modeled monthly mean discharges during 1985-97 against their observed counterparts (Archer 2003), together with their confidence interval (mean's confidence interval with a significance level of $95 \%$ was calculated using model's simulations during 1985-97). During the peak months (July and August), the model reproduces the observations quite well, and even during rising months (April-June) these are well represented, while some criticalities arise in fall, when October and November (low) discharges are slightly overestimated by the model. In Fig. 4 we display the contribution to flow of three components, namely, rainfall (plus subsuperficial flow) and fast surface flow from ice melt and snowmelt (lumped), as estimated by the model during 1985-97. Snowmelt carries half of the total discharge until May and then shifts to a lower share in favor of ice melting, which in August and September represents a very large share of total streamflow $(74 \%$ and $87 \%$, respectively).

Comparing daily discharges from the model during May-November 2012 against observations (not shown), we obtained an NSE of 0.94 and an RMSE of $69.2 \mathrm{~m}^{3} \mathrm{~s}^{-1}$, with a "good" level of agreement (using the fitness evaluation tool named FITEVAL software; see Ritter and Muñoz-Carpena 2013).

We also carried out a comparison (to be taken as indicative, given the short series) of the model's performance against 1 ) daily stream flows in Paiju as estimated using our hydrometric station during May-June 2012 and 2) snow depth data at the Concordia station from winter 2011 to summer 2012. Comparison statistics against Paiju station data are reported in Table 4. Here, the model provided an "acceptable" (FITEVAL) score $\left(\mathrm{NSE}=0.76, \mathrm{RMSE}=7.6 \mathrm{~m}^{3} \mathrm{~s}^{-1}\right)$.

Comparison of snow depth measured in Concordia (4682 m MSL) by a sonic ranger during winter 2011/12 provided a visually acceptable fit (RMSE $=84.7 \mathrm{~mm}$ ). Briefly, SWE estimated using the sonic ranger during May 2012 was approximately $120 \mathrm{~mm}$ SWE, and an approximate depletion date was seen on the first days of June, whereas the model within the relative altitude belt (average altitude $4700 \mathrm{~m}$ MSL) provided an SWE of approximately $140 \mathrm{~mm}$, similar to the one at the sonic ranger but with later depletion at the end of June. SWE modeled during 2009-11 was also compared against accumulation data from the snow pits dug in summer 2011 (see Table 1). The data from the two snow pits taken in August 2011 that we could use (at 5600 and $5900 \mathrm{~m}$ MSL) provided values of 2460 and $3280 \mathrm{~mm}$ SWE during 2009-11. The model's SWE estimation within the two relative altitude belts (Fig. 5) was 2659 and $3012 \mathrm{~mm}$, respectively. Pointwise comparison of snow dynamics is always difficult, given the highly variable local conditions of snow cover, and the proposed results need be considered carefully. However, given the reasonable correspondence we found, and the fact that the comparison of modeled snow cover against MODIS images carried out by Bocchiola et al. (2011) provided acceptable accuracy at the lowest altitude, we may assume here that 1) snow cover dynamics is reasonably well depicted by our model in the area and 2) accumulation at the highest altitudes is reasonably well described using our Eq. (1) for precipitation at the highest altitudes. 


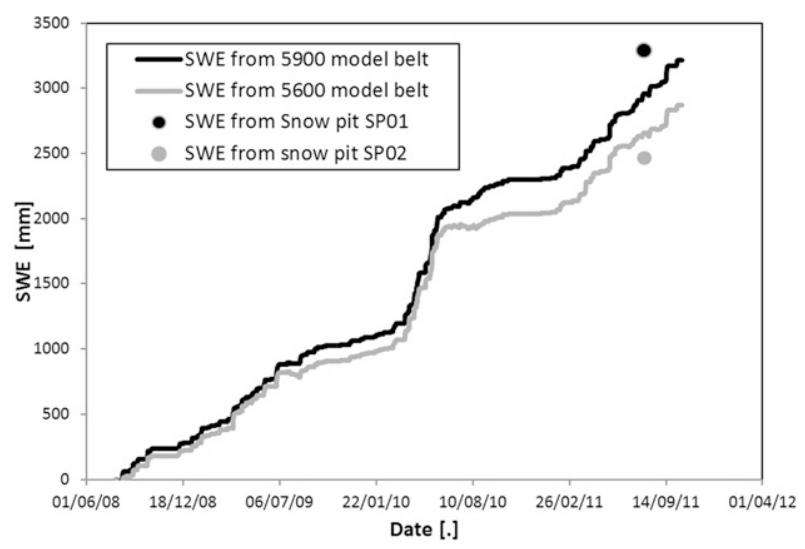

FIG. 5. Snow accumulation during 2009-11 in the accumulation area of Baltoro glacier measured by snow pits and mimicked by the model.

\section{c. Climate projections 2012-2100}

High-resolution climate projections obtained by downscaling EC-EARTH, CCSM4, and ECHAM6 under the three RCP scenarios have been used to calculate future temperature and precipitation. Tables 5 and 6 summarize the monthly changes in the two reference decades (2045-54 and 2090-99) against the control period (1980-2012) for temperature and precipitation, respectively. As far as temperature is concerned, all models and scenarios display a similar situation, providing an increase near $0.85^{\circ}, 2.5^{\circ}$, and $5.3^{\circ} \mathrm{C}$ toward the end of the century (2090-99) under the RCP2.6, RCP4.5, and RCP8.5 scenarios, respectively.

Except for a few cases, our simulations for the future decades project a monthly temperature increase toward midcentury, compared to the reference period 19802012, ranging from $1.2^{\circ}$ (obtained with EC-EARTH under the RCP2.6 scenario) to $2.24^{\circ} \mathrm{C}$ (CCSM4 under the RCP8.5 scenario), as shown in Table 5. Long-term projections under the RCP2.6 scenario are such that the temperature at the end of the century will be lower than at midcentury, but still higher than current values [lowest temperature increase is $0.82^{\circ} \mathrm{C}$ shown by the ECHAM6 at the end of the century with respect to the control period (CO) and $-0.62^{\circ} \mathrm{C}$ with respect to 2040 49 variation], while the end-of-century temperature increase will range from $2.31^{\circ}$ to $3.00^{\circ} \mathrm{C}$ (RCP4.5) and from $5.09^{\circ}$ to $5.69^{\circ} \mathrm{C}(\mathrm{RCP} 8.5)$ with respect to the present-day value.

Precipitation is generally projected to increase, but differently with models and scenarios. In the first reference decade (2040-49), CCSM4 displays a slight decrease yearly, but toward at the end of the century precipitation increases in all scenarios, with changes up to $30 \%$.
Yearly precipitation change at midcentury, compared to the reference value in Askole $\left(207 \mathrm{~mm} \mathrm{yr}^{-1}\right.$ average in 1980-2012; Table 6), ranges from -2.2\% (ECHAM6) to $7.9 \%$ (EC-EARTH) under the RPC2.6 scenario, from $-5.9 \%$ (CCSM4) to $11.9 \%$ (EC-EARTH) under the RCP4.5 scenario, and from $-5.6 \%$ (CCSM4) to $16.3 \%$ (EC-EARTH) under the RCP8.5, displaying a range of variation depending on the model input, the scenario, and the season. During 2090-99, on the other hand, precipitation is always projected to increase, up to $8.3 \%$ for RCP2.6 (ECHAM6), $10.5 \%$ for RCP4.5 (ECHAM6), and $30.5 \%$ for RCP8.5 (EC-EARTH).

\section{d. Hydrological projections 2012-2100}

In Fig. 6, we report modified monthly discharge per reference decade under all scenarios. Annual mean discharge variations during 2040-49 are positive, with an increase between $5 \%$ and $12 \%$ for RCP2.6, between $11 \%$ and $25 \%$ for RCP 4.5 , and between $12 \%$ and $23 \%$ for RCP 8.5 . Mean yearly discharge $E[Q]$ reaches $1061 \mathrm{~mm} \mathrm{yr}^{-1}$ (ECHAM6 versus $943 \mathrm{~mm} \mathrm{yr}^{-1}$ CO) under RCP2.6, $1184 \mathrm{~mm} \mathrm{yr}^{-1}$ (EC-EARTH) under RCP4.5, and $1156 \mathrm{~mm} \mathrm{yr}^{-1}$ (ECHAM6) under RCP8.5. Toward the end of the century, the situation is similar for RCP8.5, while RCP4.5 shows a minor increase, between $3 \%$ and $15 \%$, and RCP2.6 displays a decrease, around $-15 \%$ for all models. The $E[Q]$ decreases under RCP2.6 by $-20 \%\left(806 \mathrm{~mm} \mathrm{yr}^{-1}\right)$, and it increases under RCP4.5 and RCP8.5, reaching 1007 (lower than $E[Q]$ at midcentury) and $1175 \mathrm{~mm} \mathrm{yr}^{-1}$, respectively, which is still higher than for the $\mathrm{CO}$ period.

Some statistical indicators have been evaluated (not shown), like $Q_{37}, Q_{91}, Q_{182}$, and $Q_{274}$, under the different scenarios averaged on the reference decades, to be compared against those during the control period. Also, we calculated the decadal average of the yearly values of the greatest and least flows expected within the Shigar River for increasingly longer periods $d, Q_{M, d}$, and $Q_{m, d}$, for $d=37,91,182$, and 274 days.

Our chosen flow descriptors are in practice always higher than in the CO case in the 2040-49 period, and only EC-EARTH shows decreasing values under all scenarios during 2090-99. The increasing values of largest flows for fixed periods $Q_{M, d}$, say for $d=37$ and 91 days under RCP4.5 and RCP8.5, respectively, indicates the potential for heavier floods during flood season from June to October. Future snow cover on 1 October (SWE; cubic meters of water) per altitude belt for the future (average 2040-49 and average 2090-99) is reported in Fig. 7.

The volume of water in SWE changes at midcentury within $-5.4 \%$ (ECHAM6) and $-36.8 \%$ (EC-EARTH) under RCP2.6, within $-29.4 \%$ (EC-EARTH) and $13.5 \%$ (CCSM4) under RCP4.5, and within $-30.5 \%$ (CCSM4) 


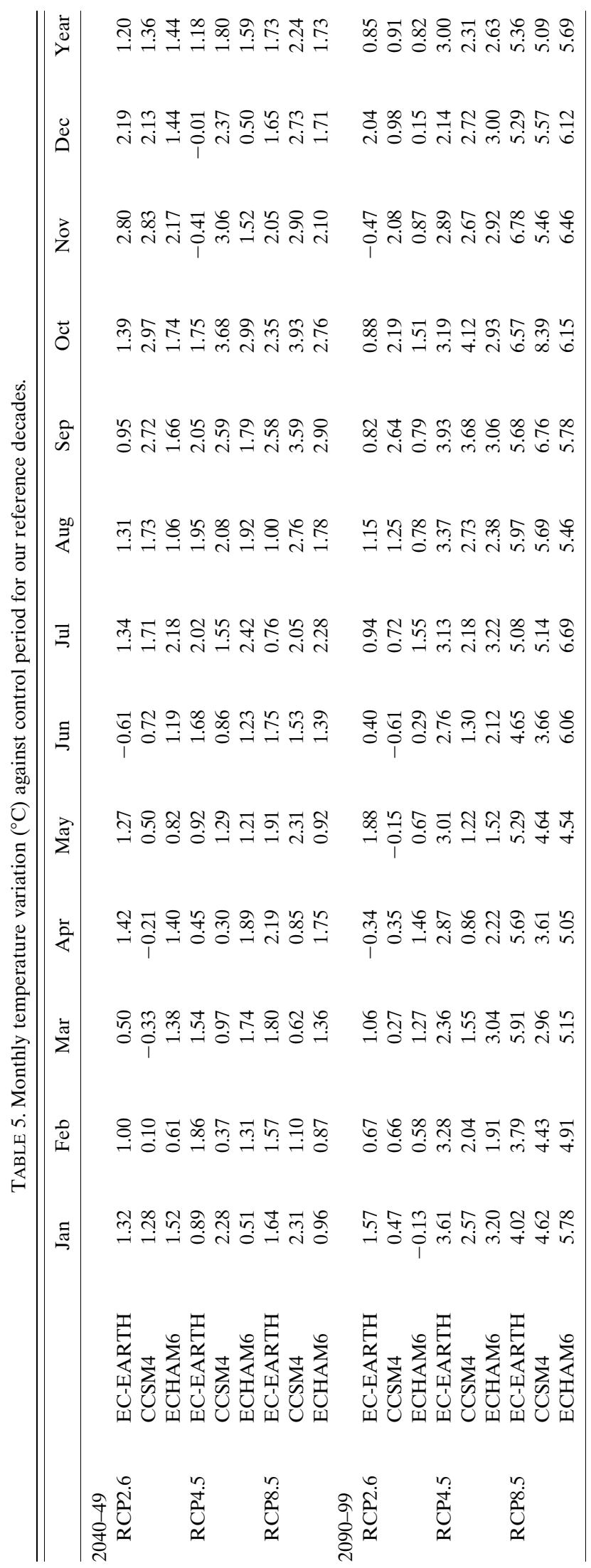




\begin{tabular}{|c|c|c|}
\hline$\vec{\Xi}$ & 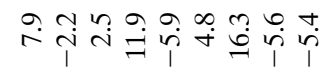 & 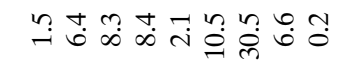 \\
\hline $\begin{array}{l}\mathscr{U} \\
\stackrel{\Delta}{0}\end{array}$ & & 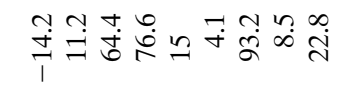 \\
\hline$\vec{z}$ & 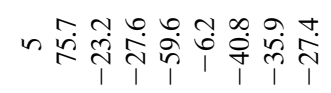 & 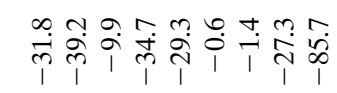 \\
\hline $\overrightarrow{\tilde{O}}$ & 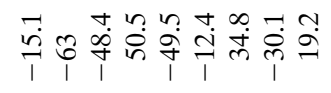 & 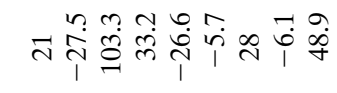 \\
\hline ळे & 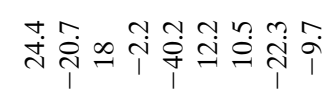 & 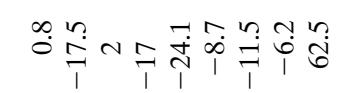 \\
\hline$\stackrel{\infty}{z}$ & 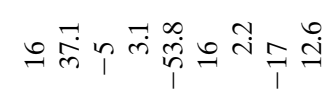 & 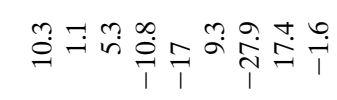 \\
\hline$\Xi$ & 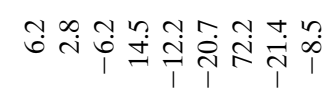 & 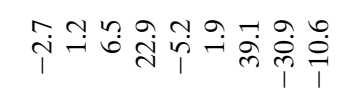 \\
\hline$\Xi$ & 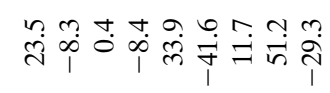 & 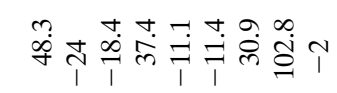 \\
\hline$\vec{\Sigma}$ & 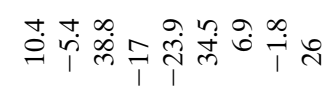 & 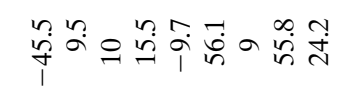 \\
\hline $\overrightarrow{\mathrm{s}}$ & 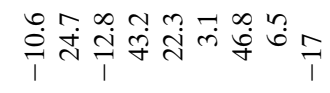 & 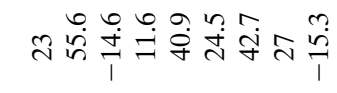 \\
\hline$\sum_{\Sigma}^{ \pm}$ & 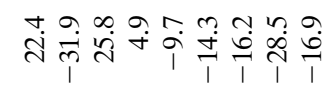 & 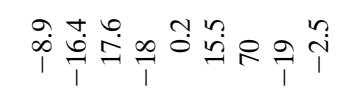 \\
\hline $\begin{array}{l}\overrightarrow{0} \\
0 \\
\end{array}$ & 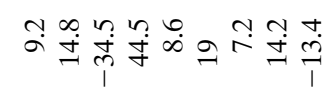 & 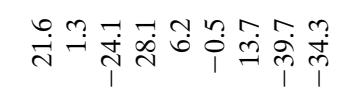 \\
\hline శే & 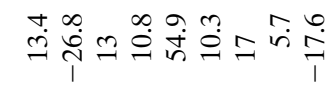 & 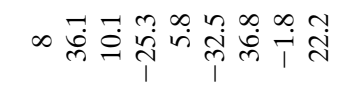 \\
\hline & 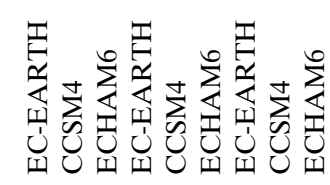 & 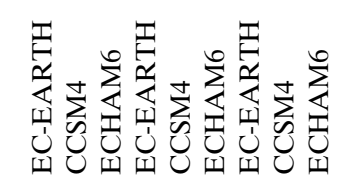 \\
\hline & 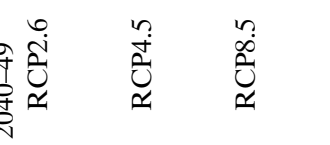 & 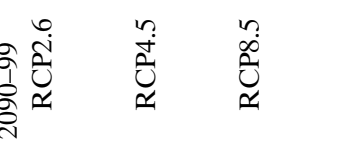 \\
\hline
\end{tabular}



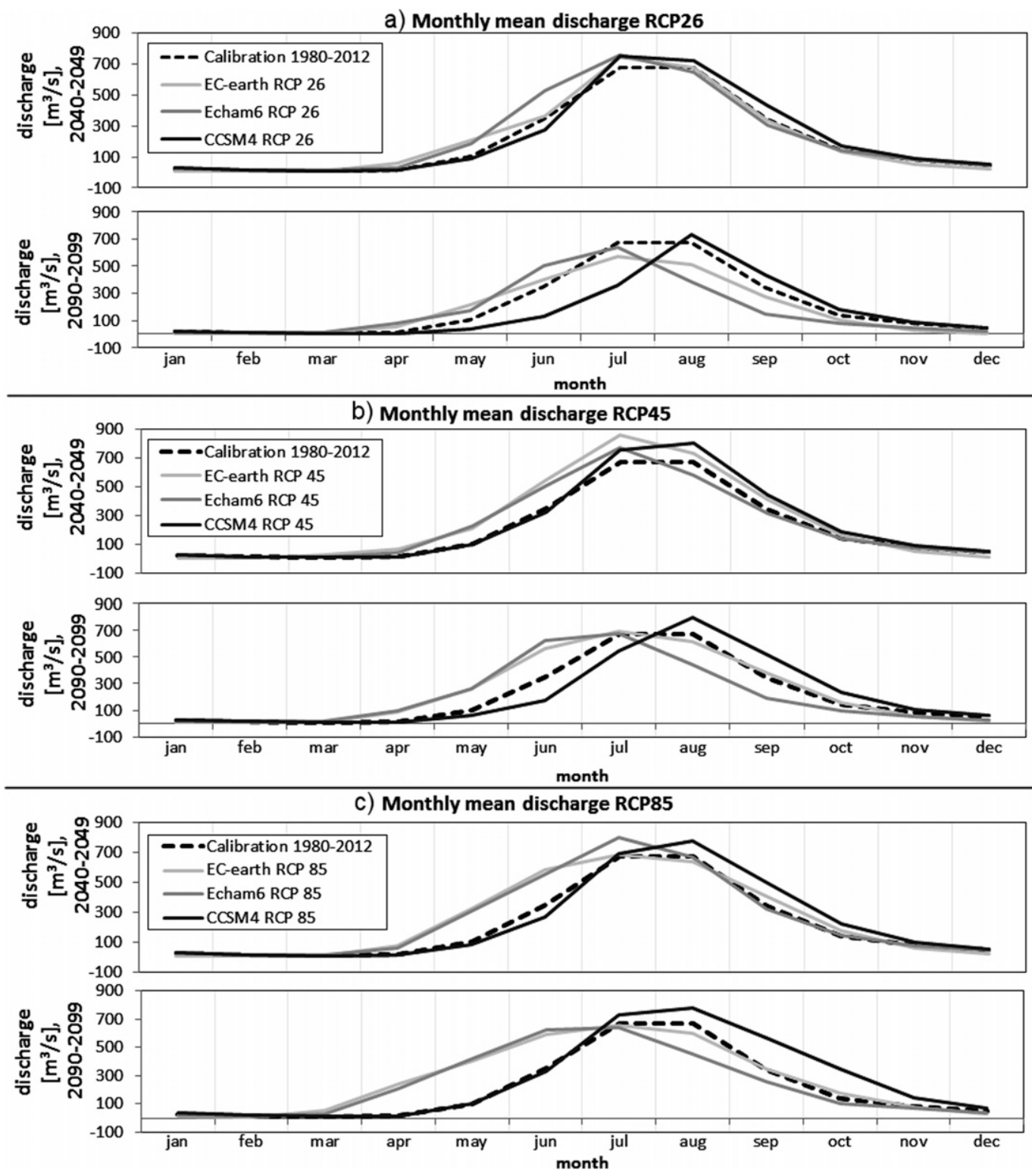

FIG. 6. Shigar River at Shigar bridge. Monthly projected discharges, averaged for reference decades: (a) RCP2.6, (b) RCP4.5, and (c) RCP8.5.

and $3.3 \%$ (EC-EARTH) under RCP8.5. At the end of the century, SWE volume is between $-28.5 \%$ (ECHAM6) and $-1.6 \%$ (CCSM4) under RCP2.6, between $-50.4 \%$ (CCSM4) and $-3.93 \%$ (ECHAM6) under RCP4.5, and between and $-68.2 \%$ (ECHAM6) and $-60.7 \%$ (ECEARTH) under RCP8.5, with oscillating, yet always negative, values.

Future ice cover (also expressed in cubic meters of water) is reported in Fig. 8, per altitude bin, and is averaged for reference decades. While at midcentury ice cover area remains constant $(-0.13 \%$ on average for all RCPs), with a slight change in ice volume $(-8.93 \%,-10.95 \%$, and
$-11.00 \%$ on average for RCP2.6, RCP4.5, and RCP8.5, respectively) with similar behavior for all GCMs, toward the end of the century different RCPs provide different ice cover areas $(-20.71 \%,-22.92 \%$, and $-42.8 \%$ on average for RCP2.6, RCP4.5, and RCP8.5, respectively) and ice volume $(-60.41 \%,-72.84 \%$, and $-89.2 \%$ on average for $\mathrm{RCP} 2.6, \mathrm{RCP} 4.5$, and RCP8.5, respectively).

\section{Discussion}

We investigated the hydrological behavior of the Shigar River catchment in the upper Karakoram, which 
a) Snow Water Equivalent accumulation RCP26
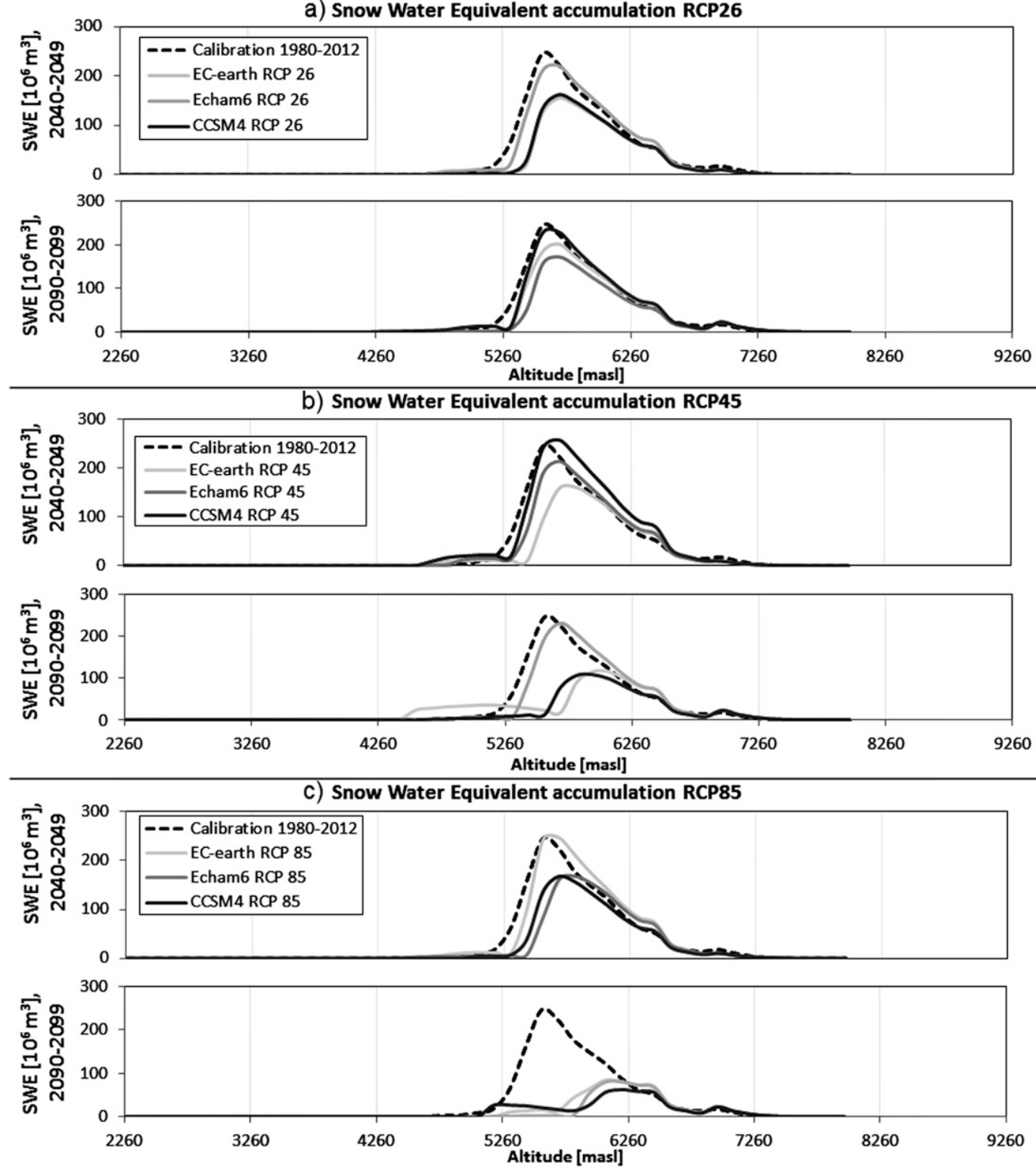

FIG. 7. Shigar River catchment. Projected SWE volume per altitude bin on 1 Oct, averaged for reference decades: (a) RCP2.6, (b) RCP4.5, and (c) RCP8.5.

is paradigmatic of hydrological behavior under the Karakoram anomaly. In particular, we considered field data of ice ablation, snow accumulation, hydrological fluxes, and approximate ice thickness collected during 2011-13 to initialize, constrain, or validate a glaciohydrological model aimed at representing the most important processes driving the hydrological fluxes in this area. Validation of the modeled snow dynamics against SWE data from high-altitude snow pits, snow data collected at the Concordia automatic weather station, and MODIS images (see Bocchiola et al. 2011) displayed acceptable performance of our model in depicting high-altitude snow dynamics. Observed ice ablation, estimated ice velocity from our stakes, remote sensing data from literature, and approximate ice depth inferred from local surveys are used to set up our simple ice flow model. The model was able to reproduce the hydrological fluxes reasonably well that were directly measured in Paiju, near the Baltoro glacier, and more downstream at Shigar, therefore displaying a capability to mimic in a consistent way the past and current water budget and the hydrological behavior of this complex area, accounting for the contribution of the different physical processes (i.e., snowmelt, ice melt, and liquid precipitation) to instream fluxes (Fig. 4). 
a) Ice volume RCP26

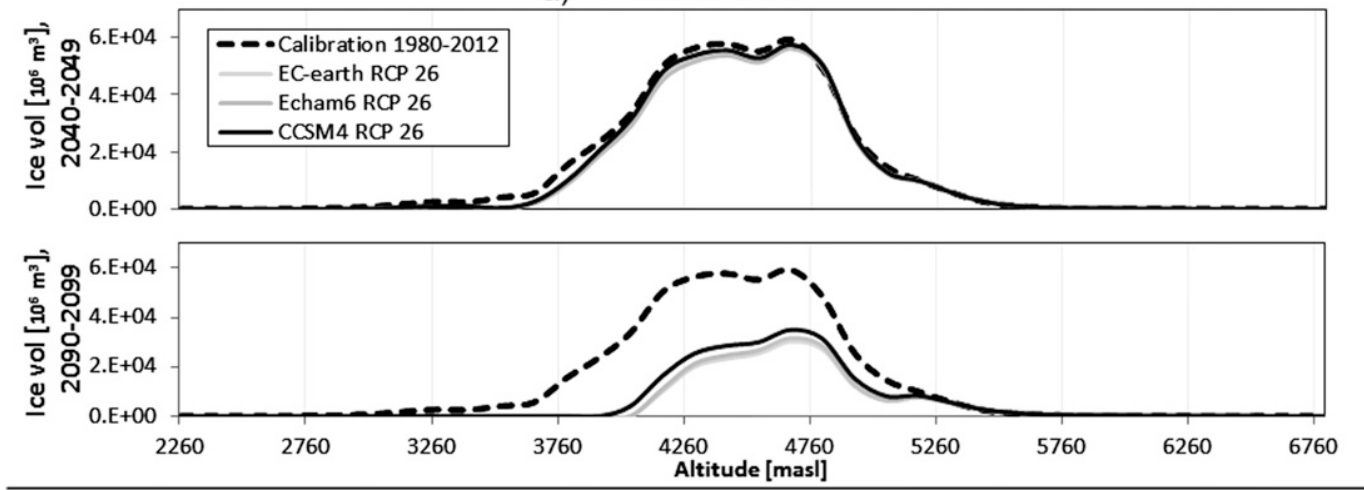

b) Ice volume RCP45
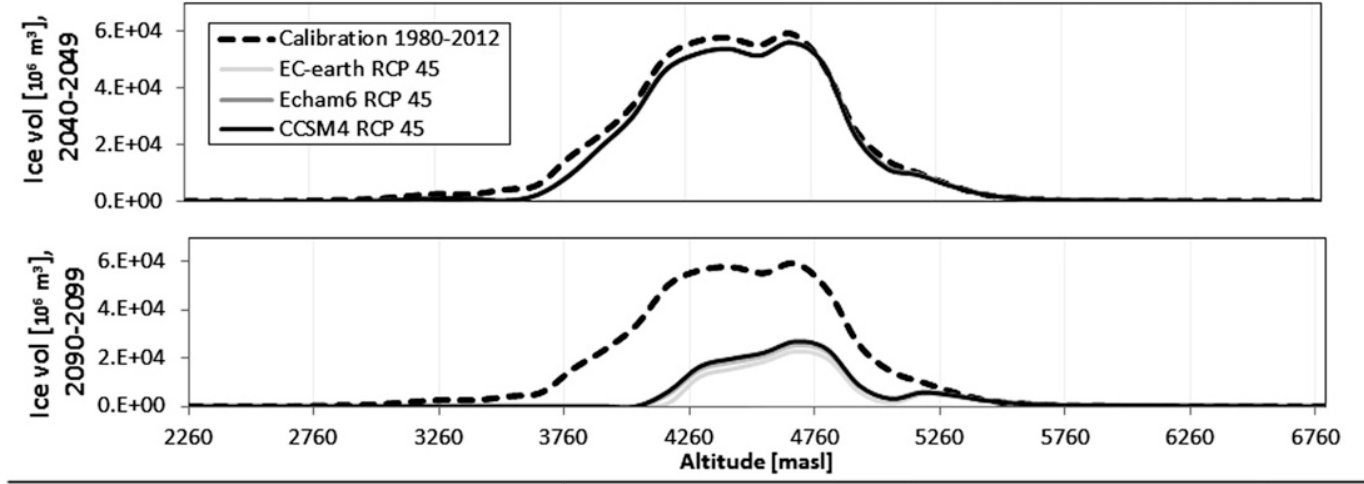

C) Ice volume RCP85

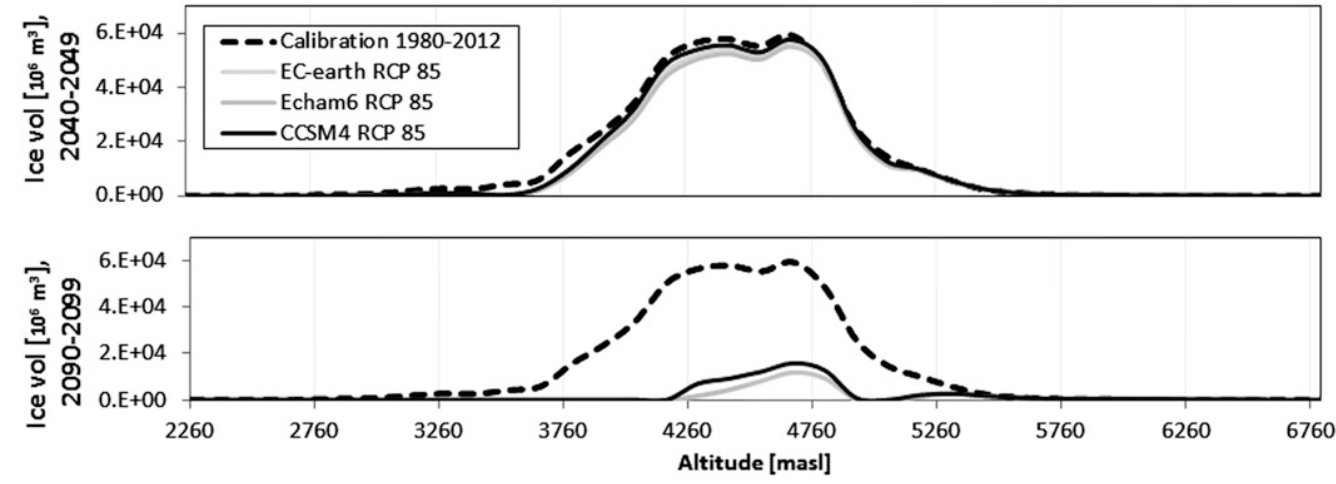

FIG. 8. Shigar River catchment. Projected water volume in ice per altitude bin on 1 Nov, averaged for reference decades: (a) RCP2.6, (b) RCP4.5, and (c) RCP8.5.

Scientists in the area of glaciology put forward the concept of the Karakoram anomaly to emphasize the difference between substantially unchanged snow and ice cover and glacier stability in the central Karakoram and the general shrinking of eastern Himalayan glaciers in the last few decades (Hewitt 2005; Kääb et al. 2012; Bocchiola and Diolaiuti 2013; Gardelle et al. 2012; Minora et al. 2013). Our simulations for the control period (1980-2012) displayed no significant changes in snow or ice cover, ice depth, or instream discharges (not shown), which substantiates the hypothesis of stable behavior underpinning the Karakoram anomaly. For instance, our modeled ice loss during 2003-08 $\left(-0.25 \mathrm{~m} \mathrm{yr}^{-1}\right)$ is comparable with that reported for that period in the Karakoram by Kääb et al. $(2012 ;-0.21 \pm$ $0.05 \mathrm{~m} \mathrm{yr}^{-1}$ ).

We projected the hydrological behavior of the Shigar catchment until the end of the twenty-first century by feeding the model with the (downscaled) precipitation and temperature output from three different global climate models participating in CMIP5 (Alexander et al. 2013), run under the RCP2.6, RCP4.5, and RCP 8.5 scenarios. Midterm projections obtained under the three RCP scenarios show a slight decrease of both snow and 
ice cover for the period 2040-49 (Figs. 6-8), suggesting that the anomalous behavior of the Karakoram cryosphere may substantially persist in the near future. Over longer time scales, however, our projections indicate a substantial decrease of snow and ice cover, leading to a large loss of snow/ice mass in a period of approximately 50 years and consequent decrease in stream flows.

Among others, Immerzeel et al. (2009) investigated the effects of snow and ice melt contribution to the discharge of the Indus River, concluding that stream flows can be predicted using a snowmelt runoff model (SRM) driven by remotely sensed precipitation and snow cover data and calibrated using daily discharge data. They investigated the future (2071-2100) effects of retreating glaciers on the discharge of the upper Indus River. They found a clear warming trend in all seasons in the upper Indus basin, increasing with elevation, and reduced snowfall, whereas total precipitation was found to increase by approximately $20 \%$. They also found that snowmelt peaks shifted up to one month earlier, and found increased glacial flow due to temperature rise and a significant increase of rainfall runoff. Immerzeel et al. (2013) used a glaciohydrological model describing ice flow dynamics of the Baltoro glacier, providing future projections until 2100, under the RCP4.5 and RCP8.5 climate scenarios. They found that discharge may increase along the century, with glacier melt slightly decreasing and precipitation runoff increasing instead. They estimated an ice volume loss near $-55 \%$ by 2100 . However, they did not use field data from the Baltoro glacier, and they made a number of simplifying assumptions concerning, among others, ice ablation and ice flow, so comparison with our results here may only be indicative.

According to our projections, the future hydrological cycle (Fig. 6, monthly discharges) may display different conditions at midcentury, depending on which GCM is adopted to feed the hydrological model. In particular, EC-EARTH shows a decrease in winter and a significant increase during spring, while ECHAM6 provides a small decrease in the months from August to December (ranging from $-3 \%$ to $-20 \%$ ) and an increase in the other months, mainly in spring. Totally different are the results provided from CCSM4; in fact, it shows a slight decrease in spring (less than $-20 \%$ ) and a slight increase in discharge for all the other months. In the second reference decade, the general pattern remains the same in winter and autumn, while in spring EC-EARTH and ECHAM6 provide a very high increase of discharge, due to the early snow melt (resulting from an increase in temperature and winter snow precipitation) reaching a value around $1000 \%$ (in April EC-EARTH and
ECHAM6, under RCP8.5). At the end of the century, discharge remains high in spring. Instead, in July and August, discharge values decrease. Under the RCP2.6, discharge is lower than in the control period. This is probably because of the shrinking of ice at low altitudes combined with a relenting of the temperature increase. The discharge variability is also highly influenced by the precipitation regime, and for this reason the results depend highly on the projected GCM precipitation. It could therefore be useful to provide ensemble simulations to investigate the discharge variability range for the future under different precipitation regimes.

In the future, runoff composition may also change. Glacier melt contribution may increase until 2070, similarly to Immerzeel et al. (2013), and then start to decrease. The lack of glacier contribution will be partially compensated by an increase in precipitation, mainly during the winter season. Analysis of snow cover dynamics also provides interesting hints (Fig. 7). The reason for the increase of (average) snow water volume under RCP4.5 with CCSM4 (see section 5d) is the noticeable increase of precipitation during January (55\%; Table 6), and reduced increase in February (9\%), providing large amounts of snow during winter, which, combined with the temperature increase, may lead to decreased water volume in snow below $5500 \mathrm{~m}$ MSL but increased water volume in snow above (Fig. 7b). Increase of snow water volume under RCP8.5 is also seen for EC-EARTH. Again here, there is a large increase of precipitation (Table 6) projected during December (46.1\%), January (17\%), and February (7.2\%), with results similar to CCSM4 RCP4.5 for SWE (Fig. 7c).

Average snow-covered area (positive values of SWE in Fig. 7) at midcentury will change from $-56 \%$ (ECEARTH) to $-16.5 \%$ (ECHAM6) under RCP2.6, from $-16.5 \%$ (CCSM4) to $7.3 \%$ (EC-EARTH) under RCP4.5, and from $-46.2 \%$ (CCSM4) to $7.3 \%$ (ECEARTH). However, for EC-EARTH much less snow volume will be present (Figs. 7b,c). At the end of the century, snow-covered area will change between $-26 \%$ (EC-EARTH) and 7.4\% (CCSM4) for RCP2.6, between $-36 \%$ (ECHAM6) and 20\% (EC-EARTH) for RCP4.5, and between $-66 \%$ (EC-EARTH) and $-56 \%$ (ECHAM6, CCSM4) for RCP8.5.

In some cases a larger snow cover area is found in the projections, but with smaller SWE volumes, against $\mathrm{CO}$ (unless for CCSM4 under RCP4.5 and for EC-EARTH under RCP8.5). This is caused by the combination of precipitation and temperature changes. Precipitation and temperature scenarios from the GCMs show an increase in the variance of both variables (not shown). Given that the values of snow-covered areas above are averaged on the reference decades, low average values 
of SWE in Fig. 7 indicate that in some years a full depletion of snow could be reached at those altitudes. Thick enough snow cover (i.e., large water volumes) is a requisite for the survival of ice during the summer, so our findings here indicate that the shielding effect of snow may decrease from moderate to large by the end of the century.

As reported in section 5d, the midcentury ice cover area may remain constant with a slight change in ice volume. Toward the end of the century, the different RCPs provide different results, again with similar results for all GCMs (Fig. 8) and with slightly larger ice loss than in Immerzeel et al. (2013). Thus, even with a littleto-moderate area change, ice volume will decrease largely until the end of the century. Indeed, $80 \%$ of the ice mass here dwells between 3550 and $5600 \mathrm{~m} \mathrm{MSL}$, and this is the elevation range that will be mostly affected by rise of the snow line and ice melting. Presently, the equilibrium line altitude for the area is placed around $5200 \mathrm{~m}$ MSL (Mayer et al. 2006), while in the future it may shift, especially under RCP4.5 and RCP8.5, reaching 5500 and $5800 \mathrm{~m}$ MSL, respectively (not shown). In the RCP2.6 scenario (also called the peak and decline scenario), the model shows a significant ice volume loss at the end of the century $(-60 \%)$. This could be due to a long time lag of the glaciers to a variation in the nourishment dynamics. In fact, the temperature increase causes a decrease of the solid precipitation fraction, particularly in the area between 5000 and $6000 \mathrm{~m}$ MSL, where the greatest part of the glacierized area is located. The model projections are affected by uncertainties in reproducing the precipitation vertical gradient, as reported. It is clear that an underestimation of highaltitude precipitation (in particular, between 5000 and $6000 \mathrm{~m}$ MSL) may lead to an underestimation of the long-term glacier mass balance.

Ragettli et al. (2013) assessed the uncertainties of hydrological projections of future (until 2050) runoff from the Hunza basin, in particular those due to model parameters, climate model, and natural interannual variability. They found that parametric uncertainty may have a larger effect than other sources of uncertainty (e.g., GCM uncertainty and natural interannual variability). They further highlighted that the lack of meteorological data at high altitudes requires extrapolation, introducing additional uncertainty. Accordingly, we modeled the most important components of the hydrological cycle in the target areas by calibration against observed values whenever possible.

The PDDF approach employed in this study is quite simple compared to the complex dynamics of snow and ice melt, including the effects of debris cover. Energybased models are nowadays available for snow and ice melt (Lehning et al. 2002; Nicholson and Benn 2006; Brock et al. 2007), but they may require more information, including (present, and future for projections) subdaily solar radiation, wind velocity, and air moisture that were not available here, especially in the last 30 years. In this study, for hydrological model calibration we relied upon disaggregation of monthly data to reconstruct missing daily data, which may introduce noise at the daily scale. Estimation of ice thickness as we used here may introduce further inaccuracy. While some findings are available concerning differential ablation (e.g., Gardelle et al. 2012), an accurate assessment of ice thickness of Karakoram glaciers is yet to come, but the use of field data as demonstrated here has already provided some insight into assessing ice thickness also in reproducing ice flow velocity. Also notice that, in spite of potential errors in the assessment of absolute ice thickness, projected differential ablation (and thickness change) may already be indicative of noticeable downwasting (or accumulation) and change of ice cover. This is an asset when it comes to hydrological conjectures under future climate. Future work may be devoted to improving estimation of ice volume.

\section{Conclusions}

The Shigar River, flowing at the toe of the K2 peak and embedding the large Baltoro glacier, was hitherto little studied. Here we carried out a thorough investigation of its hydrological behavior based on new meteorological, glaciological, and hydrological field data and updated climate scenarios developed in the framework of the SHARE-PAPRIKA project, focusing on the HKH area. We highlighted the possible consequences of a warming climate on the cryosphere and downstream water resources. We projected mostly increasing instream flows in the future until the end of the century and a potential slight decrease thereafter, when ice cover (and ice thickness) will decrease sensibly. Apparently, the present Karakoram anomaly condition may only delay downwasting of ice, and increases in temperature along the century could perturb the actual equilibrium condition. Changes in precipitation amount will hardly compensate for ice loss. Accelerated ice melting will lead to an increase in floods and hazards related to glaciers' downwasting (e.g., glacial lake outburst floods, icefalls, and crevasses) in the following decades. Preliminary analysis of our future flows (not shown) indicates that projected extreme floods (i.e., maximum yearly flood for given return periods) may considerably increase until the end of the century, and further investigation should be devoted to this facet, with importance for natural hazard management and 
disaster risk assessment and reduction. The present approach profits from sparse observed data from several sources, and it can be reasonably applied to other catchments nearby provided that some basic information about topography, climate, and glaciology are available. Our study describes a tool that can be used to assess the future hydrological behavior in highaltitude glacierized catchments similar to the one analyzed here, which is also useful for policy makers for adaptation purposes.

Acknowledgments. The present work was carried out at the conclusion of the SHARE-PAPRIKA project, funded by the Ev-K2-CNR Association of Italy, aimed at evaluating the impact of climate change on hydrology of the upper Indus River. We hereby acknowledge the Ev-K2-CNR Committee, particularly Dr. Elisa Vuillermoz, and the Pakistan Meteorological Department (PMD) for providing weather data from their stations in northern Pakistan. Eng. Ester Nana, Dr. Chiara Compostella, Dr. Umberto Minora, Dr. Boris Mosconi, Mr. Luigi Bonetti (attending the field trip with kind permission of ARPA Lombardia), Dr. Furrukh Bashir, Dr. Habibullah Brohi, Dr. Adnan Shafiq Rana, and Dr. Faizal Dukhi are kindly acknowledged for participating in the field campaigns in fulfillment of the PAPRIKA project. We acknowledge the World Climate Research Programme's Working Group on Coupled Modelling, which is responsible for CMIP, and we thank the climate modeling groups (listed in Table 2 of this paper) for producing and making available their model output. For CMIP, the U.S. Department of Energy's Program for Climate Model Diagnosis and Intercomparison provides coordinating support and led development of software infrastructure in partnership with the Global Organization for Earth System Science Portals.

\section{REFERENCES}

Ageta, Y., and T. Kadota, 1992: Predictions of changes of glacier mass balance in the Nepal Himalaya and Tibetan Plateau: A case study of air temperature increase for three glaciers. Ann. Glaciol., 16, 89-94.

Aggarwal, P. K., P. K. Joshi, J. S. I. Ingram, and R. K. Gupta, 2004: Adapting food systems of the Indo-Gangetic plains to global environmental change: Key information needs to improve policy formulation. Environ. Sci. Policy, 7, 487-498, doi:10.1016/ j.envsci.2004.07.006.

Aizen, V. B., E. M. Aizen, and S. A. Nikitin, 2002: Glacier regime on the northern slope of the Himalaya (Xixibangma glaciers). Quat. Int., 97-98, 27-39, doi:10.1016/S1040-6182(02)00049-6.

Akhtar, M., N. Ahmad, and M. J. Booij, 2008: The impact of climate change on the water resources of HindukushKarakoram-Himalaya region under different glacier coverage scenario. J. Hydrol., 355, 148-163, doi:10.1016/ j.jhydrol.2008.03.015.
Alexander, L. V., and Coauthors, 2013: Summary for policymakers. Climate Change 2013: The Physical Science Basis, T. F. Stocker et al., Eds., Cambridge University Press, 3-29.

Anders, A. M., G. H. Roe, B. Hallet, D. R. Montgomery, N. J. Finnegan, and J. Putkonen, 2006: Spatial patterns of precipitation and topography in the Himalaya. Spec. Pap. Geol. Soc. Amer., 298, 39-53.

Archer, D. R., 2003: Contrasting hydrological regimes in the upper Indus basin. J. Hydrol., 274, 198-210, doi:10.1016/ S0022-1694(02)00414-6.

, and H. J. Fowler, 2004: Spatial and temporal variations in precipitation in the upper Indus basin, global teleconnections and hydrological implications. Hydrol. Earth Syst. Sci., 8, 47 61, doi:10.5194/hess-8-47-2004.

Barrand, N. E., and T. Murray, 2006: Multivariate controls on the incidence of glacier surging in the Karakoram Himalaya. Arct. Antarct. Alp. Res., 38, 489-498, doi:10.1657/ 1523-0430(2006)38[489:MCOTIO]2.0.CO;2.

Baumann, S., and S. Winkler, 2010: Parameterization of glacier inventory data from Jotunheimen/Norway in comparison to the European Alps and the Southern Alps of New Zealand. Erdkunde, 64, 155-177, doi:10.3112/erdkunde.2010.02.04.

Bocchiola, D., and G. Diolaiuti, 2013: Recent (1980-2009) evidence of climate change in the upper Karakoram, Pakistan. Theor. Appl. Climatol., 113, 611-641, doi:10.1007/ s00704-012-0803-y.

— for extreme floods design: A case study in Italy. Adv. Water Resour., 32, 1284-1296, doi:10.1016/j.advwatres.2009.05.005.

— , and Coauthors, 2011: Prediction of future hydrological regimes in poorly gauged high altitude basins: The case study of the upper Indus, Pakistan. Hydrol. Earth Syst. Sci., 15, 20592075, doi:10.5194/hess-15-2059-2011.

Bolch, T., T. Pieczonka, and D. I. Benn, 2011: Multi-decadal mass loss of glaciers in the Everest area (Nepal Himalaya) derived from stereo imagery. Cryosphere, 5, 349-358, doi:10.5194/ tc-5-349-2011.

Bookhagen, B., and D. W. Burbank, 2006: Topography, relief, and TRMM-derived rainfall variations along the Himalaya. Geophys. Res. Lett., 33, L08405, doi:10.1029/2006GL026037.

_ , and _ 2010: Towards a complete Himalayan hydrologic budget: Spatiotemporal distribution of snow melt and rainfall and their impact on river discharge. J. Geophys. Res., 115, F03019, doi:10.1029/2009JF001426.

Brock, B. W., A. Rivera, G. Casassa, F. Bown, and C. Acuña, 2007: The surface energy balance of an active ice-covered volcano: Volcán Villarrica, southern Chile. Ann. Glaciol., 45, 104-114, doi:10.3189/172756407782282372.

Ceres, F., G. B. Chirico, and N. Romano, 2009: Considerazioni sulla stima della capacità idrica di campo in suoli uniformi e stratificati (Assessment of water contentwithinuniform and stratifiedsoils). Proc. IX Convegno Nazionale dell'Associazione Italiana di Ingegneria Agraria, Ischia Porto, ARB, Memoria 3-44.

Chen, J. M., X. Chen, W. Ju, and X. Geng, 2005: Distributed hydrological model for mapping evapotranspiration using remote sensing inputs. J. Hydrol., 305, 15-39, doi:10.1016/ j.jhydrol.2004.08.029.

Copland, L., T. Sylvestre, M. P. Bishop, J. F. Shroder, Y. B. Seong, L. A. Owen, A. Bush, and U. Kamp, 2011: Expanded and recently increased glacier surging in the Karakoram. Arct. Antarct. Alp. Res., 43, 503-516, doi:10.1657/1938-4246-43.4.503.

Cuffey, K. M., and W. S. B. Paterson, 2010: The Physics of Glaciers. 4th ed. Academic Press, 704 pp. 
Diolaiuti, G., M. Pecci, and C. Smiraglia, 2003: Liligo glacier, Karakoram, Pakistan: A reconstruction of the recent history of a surge-type glacier. Ann. Glaciol., 36, 168-172, doi:10.3189/ 172756403781816103.

Fowler, H. J., and D. R. Archer, 2005: Hydro-climatological variability in the upper Indus basin and implications for water resources. IAHS Publ., 295, 131-138. [Available online at http:// iahs.info/uploads/dms/13164.22\%20131-138\%20(Fowler).pdf.]

Gardelle, J., E. Berthier, and Y. Arnaud, 2012: Slight mass gain of Karakoram glaciers in the early twenty-first century. Nat. Geosci., 5, 322-325, doi:10.1038/ngeo1450.

Groppelli, B., D. Bocchiola, and R. Rosso, 2011a: Spatial downscaling of precipitation from GCMs for climate change projections using random cascades: A case study in Italy. Water Resour. Res., 47, W03519, doi:10.1029/2010WR009437.

- - A. Soncini, D. Bocchiola, and R. Rosso, 2011b: Evaluation of future hydrological cycle under climate change scenarios in a mesoscale Alpine watershed of Italy. Nat. Hazards Earth Syst. Sci., 11, 1769-1785, doi:10.5194/nhess-11-1769-2011.

Hannah, D. M., S. L. Kansakar, A. J. Gerrard, and G. Rees, 2005: Flow regimes of Himalayan rivers of Nepal: Nature and spatial patterns. J. Hydrol., 308, 18-32, doi:10.1016/ j.jhydrol.2004.10.018.

Hewitt, K., 2005: The Karakoram Anomaly? Glacier expansion and the 'elevation effect,' Karakoram Himalaya. Mt. Res. Dev., 25, 332-340, doi:10.1659/0276-4741(2005)025[0332: TKAGEA]2.0.CO;2.

Immerzeel, W. W., P. Droogers, S. M. de Jong, and M. F. P. Bierkens, 2009: Large-scale monitoring of snow cover and runoff simulation in Himalayan river basins using remote sensing. Remote Sens. Environ., 113, 40-49, doi:10.1016/ j.rse.2008.08.010.

— L. P. H. van Beek, and M. F. P. Bierkens, 2010: Climate change will affect the Asian water towers. Science, 328, 13821385, doi:10.1126/science. 1183188.

— , F. Pellicciotti, and A. B. Shrestha, 2012a: Glaciers as a proxy to quantify the spatial distribution of precipitation in the Hunza basin. Mt. Res. Dev., 32, 30-38, doi:10.1659/ MRD-JOURNAL-D-11-00097.1.

- , L. P. H. Van Beek, M. Konz, A. B. Shrestha, and M. F. P. Bierkens, 2012b: Hydrological response to climate change in a glacierized catchment in the Himalayas. Climatic Change, 110, 721-736, doi:10.1007/s10584-011-0143-4.

—_, F. Pellicciotti, and M. F. P. Bierkens, 2013: Rising river flows throughout the twenty-first century in two Himalayan glacierized watersheds. Nat. Geosci., 6, 742-745, doi:10.1038/ ngeo1896.

JPL, cited 2014: ASTER Digital Elevation Model-AST14DEMRelative. [Available online at http://asterweb.jpl.nasa.gov/ content/03_data/01_Data_Products/release_DEM_relative.htm.]

Kääb, A., E. Berthier, C. Nuth, J. Gardelle, and Y. Arnaud, 2012: Contrasting patterns of early twenty-first-century glacier mass change in the Himalayas. Nature, 488, 495-498, doi:10.1038/ nature11324.

Kahlown, M. A., A. Raoof, M. Zubair, and W. D. Kemper, 2007: Water use efficiency and economic feasibility of growing rice and wheat with sprinkler irrigation in the Indus basin of Pakistan. Agric. Water Manage., 87, 292-298, doi:10.1016/ j.agwat.2006.07.011.

Kaser, G., M. Großhauser, and B. Marzeion, 2010: Contribution potential of glaciers to water availability in different climate regimes. Proc. Natl. Acad. Sci., 107, 20223-20227, doi:10.1073/pnas.1008162107.
Kehrwald, N. M., and Coauthors, 2008: Mass loss on Himalayan glacier endangers water resources. Geophys. Res. Lett., 35, L22503, doi:10.1029/2008GL035556.

Lehning, M., P. Bartelt, B. Brown, and C. Fierz, 2002: A physical SNOWPACK model for the Swiss avalanche warning: Part III: Meteorological forcing, thin layer formation and evaluation. Cold Reg. Sci. Technol., 35, 169-184, doi:10.1016/ S0165-232X(02)00072-1.

Mayer, C., A. Lambrecht, M. Belò, C. Smiraglia, and G. Diolaiuti, 2006: Glaciological characteristics of the ablation zone of Baltoro glacier, Karakoram. Ann. Glaciol., 43, 123-131, doi:10.3189/172756406781812087.

— A. C. Fowler, A. Lambrecht, and K. Scharrer, 2011: A surge of North Gasherbrum glacier, Karakoram, China. J. Glaciol., 57, 904-916, doi:10.3189/002214311798043834.

Mihalcea, C., C. Mayer, G. Diolaiuti, A. Lambrecht, C. Smiraglia, and G. Tartari, 2006: Ice ablation and meteorological conditions on the debris covered area of Baltoro glacier (Karakoram, Pakistan). Ann. Glaciol., 43, 292-300, doi:10.3189/172756406781812104.

, — - —, C. D'Agata, C. Smiraglia, A. Lambrecht, E. Vuillermoz, and G. Tartari, 2008: Spatial distribution of debris thickness and melting from remote-sensing and meteorological data, at debris-covered Baltoro glacier, Karakoram, Pakistan. Ann. Glaciol., 48, 49-57, doi:10.3189/ 172756408784700680.

Minora, U., and Coauthors, 2013: 2001-2010 glacier changes in the Central Karakoram National Park: A contribution to evaluate the magnitude and rate of the Karakoram anomaly. Cryosphere Discuss., 7, 2891-2941, doi:10.5194/tcd-7-2891-2013.

Moss, R. H., and Coauthors, 2010: The next generation of scenarios for climate change research and assessment. Nature, 463, 747756, doi:10.1038/nature 08823 .

Nicholson, L., and D. Benn, 2006: Calculating ice melt beneath a debris layer using meteorological data. J. Glaciol., 52, 463470, doi:10.3189/172756506781828584.

Oerlemans, J., 2001: Glaciers and Climate Change. A. A. Balkema, 148 pp.

Palazzi, E., J. von Hardenberg, and A. Provenzale, 2013: Precipitation in the Hindu-Kush Karakoram Himalaya: Observations and future scenarios. J. Geophys. Res. Atmos., 118, 85-100, doi:10.1029/2012JD018697.

Peel, M. C., B. L. Finlayson, and T. A. McMahon, 2007: Updated world map of the Köppen-Geiger climate classification. Hydrol. Earth Syst. Sci., 11, 1633-1644, doi:10.5194/ hess-11-1633-2007.

Quincey, D. J., N. F. Glasser, M. Braun, M. P. Bishop, K. Hewitt, and A. Luckman, 2011: Karakoram glacier surge dynamics. Geophys. Res. Lett., 38, L18504, doi:10.1029/2011GL049004.

Ragettli, S., F. Pellicciotti, R. Bordoy, and W. W. Immerzeel, 2013: Sources of uncertainty in modeling the glaciohydrological response of a Karakoram watershed to climate change. Water Resour. Res., 49, 6048-6066, doi:10.1002/wrcr.20450.

Ritter, A., and R. Muñoz-Carpena, 2013: Predictive ability of hydrological models: Objective assessment of goodness-of-fit with statistical significance. J. Hydrol., 480, 33-45, doi:10.1016/ j.jhydrol.2012.12.004.

Rosso, R., 1984: Nash model relation to Horton order ratios. Water Resour. Res., 20, 914-920, doi:10.1029/WR020i007p00914.

Scherler, D., B. Bookhagen, and M. R. Strecker, 2011a: Hillslopeglacier coupling: The interplay of topography and glacial dynamics in High Asia. J. Geophys. Res., 116, F02019, doi:10.1029/2010JF001751. 
and,$- 2011 \mathrm{~b}$ : Spatially variable response of Himalayan glaciers to climate change affected by debris cover. Nat. Geosci., 4, 156-159, doi:10.1038/ngeo1068.

Sharif, M., D. R. Archer, H. J. Fowler, and N. Forsythe, 2013: Trends in timing and magnitude of flow in the upper Indus basin. Hydrol. Earth Syst. Sci., 17, 1503-1516, doi:10.5194/ hess-17-1503-2013.

Smakhtin, V. U., 2001: Low flow hydrology: A review. J. Hydrol., 240, 147-186, doi:10.1016/S0022-1694(00)00340-1.

Smiraglia, C., C. Mayer, C. Mihalcea, G. Diolaiuti, M. Belò, and G. Vassena, 2007: Ongoing variations of Himalayan and Karakoram glaciers as witnesses of global changes: Recent studies of selected glaciers. Dev. Earth Surf. Processes, 10, 235-248, doi:10.1016/S0928-2025(06)10026-7.

Solomon, S., D. Qin, M. Manning, Z. Chen, M. Marquis, K. Averyt, M. Tignor, and H. L. Miller Jr., Eds., 2007: Climate Change 2007: The Physical Science Basis. Cambridge University Press, $996 \mathrm{pp}$.
Wallinga, J., and R. S. W. van de Wal, 1998: Sensitivity of Rhonegletscher, Switzerland, to climate change: Experiments with a one-dimensional flowline model. J. Glaciol., 44, 383-393.

Wang, L., T. Koike, K. Yang, and P. J. Yeh, 2009: Assessment of a distributed biosphere hydrological model against streamflow and MODIS land surface temperature in the upper Tone River basin. J. Hydrol., 377, 21-34, doi:10.1016/ j.jhydrol.2009.08.005.

Wigmosta, M. S., L. W. Vail, and D. P. Lettenmaier, 1994: A distributed hydrology-vegetation model for complex terrain. Water Resour. Res., 30, 1665-1679, doi:10.1029/94WR00436.

Winiger, M., M. Gumpert, and H. Yamout, 2005: KarakoramHindukush-western Himalaya: Assessing high-altitude water resources. Hydrol. Processes, 19, 2329-2338, doi:10.1002/hyp.5887.

Young, G. J., and K. Hewitt, 1990: Hydrology research in the upper Indus basin, Karakoram Himalaya, Pakistan. IAHS Publ., 190, 139-152. [Available online at http://iahs.info/uploads/dms/ iahs_190_0139.pdf.] 